\title{
Targeted delivery of brain-derived neurotrophic factor for the treatment of blindness and deafness
}

\author{
This article was published in the following Dove Press journal: \\ International Journal of Nanomedicine \\ 30 April 2015 \\ Number of times this article has been viewed
}

\author{
Igor Khalin' \\ Renad Alyautdin ${ }^{2}$ \\ Ganna Kocherga ${ }^{3}$ \\ Muhamad Abu Bakar' \\ 'Faculty of Medicine and Defence \\ Health, National Defence University \\ of Malaysia, Kuala Lumpur, Malaysia; \\ ${ }^{2}$ Scientific Centre for Expertise of \\ Medical Application Products, Moscow, \\ Russia; ${ }^{3}$ Ophthalmic Microsurgery \\ Department, International Medical \\ Center Oftalmika, Kharkiv, Ukraine
}

Correspondence: Igor Khalin Faculty of Medicine and Defence Health, National Defence University of Malaysia, Sungai Besi Camp, Kuala Lumpur 57000, Malaysia

Tel +60 II III 2725

Email khalins@gmail.com

\begin{abstract}
Neurodegenerative causes of blindness and deafness possess a major challenge in their clinical management as proper treatment guidelines have not yet been found. Brain-derived neurotrophic factor (BDNF) has been established as a promising therapy against neurodegenerative disorders including hearing and visual loss. Unfortunately, the blood-retinal barrier and bloodcochlear barrier, which have a comparable structure to the blood-brain barrier prevent molecules of larger sizes (such as BDNF) from exiting the circulation and reaching the targeted cells. Anatomical features of the eye and ear allow use of local administration, bypassing histo-hematic barriers. This paper focuses on highlighting a variety of strategies proposed for the local administration of the BDNF, like direct delivery, viral gene therapy, and cell-based therapy, which have been shown to successfully improve development, survival, and function of spiral and retinal ganglion cells. The similarities and controversies for BDNF treatment of posterior eye diseases and inner ear diseases have been analyzed and compared. In this review, we also focus on the possibility of translation of this knowledge into clinical practice. And finally, we suggest that using nanoparticulate drugdelivery systems may substantially contribute to the development of clinically viable techniques for BDNF delivery into the cochlea or posterior eye segment, which, ultimately, can lead to a long-term or permanent rescue of auditory and optic neurons from degeneration.
\end{abstract}

Keywords: brain-derived neurotrophic factor, neurodegeneration, posterior eye segment, inner ear, targeted drug-delivery, nanoparticles

\section{Introduction}

Secreted protein brain-derived neurotrophic factor (BDNF) is a member of the neurotrophin family. This signaling molecule has been well-documented for its ability to regulate neuronal plasticity, cell growth, proliferation, cell survival, and long-term memory. ${ }^{1}$ Being involved in pathogenesis of neurodegenerative diseases, BDNF has become a major approach in drug development for the treatment of Alzheimer's disease, ${ }^{2}$ Parkinson's disease, ${ }^{3}$ Huntington's disease, ${ }^{4}$ Rett syndrome, ${ }^{5}$ stroke,${ }^{6}$ traumatic brain injury, ${ }^{7}$ depression, ${ }^{8}$ drug abuse,${ }^{9}$ schizophrenia, ${ }^{10}$ amniotic lateral sclerosis, ${ }^{11}$ and multiple sclerosis. ${ }^{12}$ The crucial limitation pertaining to the use of BDNF in the treatment of central nervous system (CNS) disease is its inability to cross the blood-brain barrier (BBB). In fact, numerous recent reviews have described modern accomplishments in various approaches directed to surmount the $\mathrm{BBB}$, including the modulation of tight junctions or transport systems, or the exploitation of colloid drug-delivery nanosystems. ${ }^{13-15}$

Furthermore, the retina ${ }^{16}$ and the inner ear, ${ }^{17}$ like the brain, also have their own blood barriers with similar structure and function to the BBB. Those barriers also constrain the usage of BDNF as a treatment for blindness and deafness caused by neurodegeneration of retinal or spiral ganglion cells, respectively. Fortunately, specific anatomical construction of these sensory organs offers the possibility for local drug delivery that can avoid the barriers. Eventually, the main approaches of BDNF delivery to the posterior segment 
of the eye or the inner ear appear to be similar and include direct delivery of the pure protein (intravitreous injection or implantation of the osmotic minipump to the scala tympani), viral gene, and cell-based therapy. Ultimately, this knowledge should be translated to patients, however, regardless of success in preclinical studies, BDNF has yet to prove its potential as a neurorestorative in clinics. In this review, some important points concerning the structure and mechanism of action of the BDNF are discussed. Besides, all published methods of BDNF delivery to the posterior eye segment and to the inner ear are highlighted, and additionally, these methods are analyzed and compared. Finally, future prospects in BDNF delivery that may benefit the potential treatment of blindness and deafness among patients are suggested.

\section{BDNF}

\section{BDNF structure}

BDNF belongs to the neurotrophin family of proteins, and it is the most specific in the biological action family of growth factors. Apart from BDNF, the other group members are: nerve growth factor (NGF), neurotrophin-3 (NT-3), and neurotrophin-4 (NT-4). The first neurotrophin, named NGF, was identified by Rita Levi-Montalcini in $1952^{18}$ as "unknown tumoral factor", which influenced nerve growth in mouse sarcoma and chick embryo. Thirty years later, Barde et al ${ }^{19}$ in their study on the survival and the growth of nerve fibers in neuronal cell culture, purified, $2 \mu \mathrm{g}$ of protein BDNF with a molecular weight (MW) of 12,300 Da from $3 \mathrm{~kg}$ of porcine brain. Later, the 252 amino acid (AA) residues in the sequence of BDNF were identified. ${ }^{20}$ The three-dimensional molecular structure of BDNF appears to be a homodimer with noncovalent bonds, where each monomer consists of three pairs of anti-parallel $\beta$-sheets connected to four loops of $\beta$-strands containing 3 disulfide bonds with cysteine knot motif. ${ }^{21}$ Besides, the crystallographic BDNF structure is shown in protein databases as heterodimers with NT-3 (code 1B8M) and NT-4 (code 1BND). ${ }^{22,23}$ The BDNF human gene is mapped on chromosome 11 between 11 p13 and $11 \mathrm{p} 14 .^{24,25}$ Apparently, BDNF synthesis occurs in the CNS, ${ }^{20}$ as well as in the peripheral tissues, including the liver, muscles, pancreas, colon, intestine, lungs, bladder, ${ }^{26}$ and placenta. ${ }^{27}$ It is well known that BDNF synthesis always follows a precursor molecule (pro-BDNF) synthesis, which is the 35,000 Da protein with its own CNS activity. ${ }^{28}$ The polypeptide proBDNF that consists of 247 AA residues should be cleaved to form the mature protein with a MW 14,000 Da and 119 AA residues. ${ }^{29}$ In fact, there are two existing pathways for BDNF to mature, namely the intracellular and pericellular pathways. The furin, which is located in the Golgi apparatus, plays a crucial role in the intracellular processing, ${ }^{30}$ while the pericellular pathway involves serine protease tissue plasmin, which is synthesized from plasminogen activated by the tissue plasminogen activator. ${ }^{31}$ Furthermore, it is important to note that the absence of cleavage leads to the accumulation of proBDNF that can act in a manner opposite to BDNF. In addition, studies have shown that pro-BDNF binding with p75 receptor induces neuronal apoptosis, ${ }^{32}$ whereas binding with sortilin results in a more stable form of pro-BDNF and the activation of intracellular enzyme furin. ${ }^{33}$ Additionally, the Val66Met (valine amino-acid is substituted by the methionine in 66th codon) genetic polymorphism of the pro-BDNF leads to the inability of the pro-BDNF to be bound with sortilin, resulting in a decrease in the production of mature protein that subsequently leads to numerous CNS disorders. ${ }^{34}$

\section{BDNF receptors}

BDNF is a ligand to three different receptors, namely tropomyosin related kinase B (TrkB), p75 neurotrophin receptor (p75NTR), and sortilin. It is well known that TrkB belongs to a large group of tyrosine-kinase receptors, and BDNF as well as NT-4 are the only ligands for this receptor. ${ }^{21}$ The human TrkB is a transmembrane glycoprotein type I that consists of 792 AA residues. Its extracellular domain comprises of three tandem leucine-rich motifs, bordered by two cysteine clusters, and trailed by two immunoglobulin (Ig)-like domains, $\operatorname{Ig}_{1}$ and $\operatorname{Ig}_{2},{ }^{35}$ where $\operatorname{Ig}_{2}$, the closest to cell membrane, is the binding site for BDNF. ${ }^{36}$ The receptor is capable of being in a dynamic equilibrium between monomeric and dimeric states and regulates the activity of further intracellular biochemical cascades. Moreover, binding with the ligand results in the conversion of the receptor's monomeric structure into the dimeric form, which is accompanied by autophosphorylation of the intracellular domain. ${ }^{37}$

Basically, the TrkB receptor has three core isoforms in the human brain, specifically a full-length, catalytic form (TrkB. FL), and two isoforms that lack a tyrosine kinase domain called truncated forms, namely, TrkB.T and TrkB.Shc. The truncated forms are synthesized by an alternative splicing of the primary gene and are independently regulated. ${ }^{38}$ Furthermore, the TrkB.FL is seen to be expressed in the brain cortex, the hippocampus, the thalamus, the choroid plexus, granule cell layer of the cerebellum, the brainstem, the spinal cord, and the retina. ${ }^{39}$ It initiates the survival of neuronal cells and the differentiation and plasticity of synaptic signals, whereas truncated TrkB are capable of inhibiting all these processes when their heterodimerization with the activated TrkB.FL occurs. ${ }^{40}$ Additionally, a study has shown that the relationship between levels of the TrkB.FL and the truncated isoforms 
influences the cellular response to BDNF. ${ }^{41}$ Notably, BDNF binds with TrkB.T, becoming immobilized and unable to bind with TrkB.FL, thus reducing BDNF-signaling. ${ }^{42}$ Also, the formation of TrkB.T and TrkB.FL heterodimers affects the signaling by acting as a dominant-negative inhibitor. ${ }^{43}$ Therefore, the maximal activity of TrkB is possible only in the case of homodimerization of TrkB.FL.

Another receptor, p75NTR, appears to be the 16th member of tumor necrosis factor (TNF) receptor superfamily. ${ }^{44}$ The precursors of all the four neurotrophins, such as proNGF, pro-BDNF, pro-NT-3, and pro-NT-4 are the ligands to $\mathrm{p} 75 \mathrm{NTR}$. Mature neurotrophins may also be the ligands to p75NTR, but with substantially lower affinity. ${ }^{45}$ The p75NTR structure has an extracellular stalk domain, a single transmembrane domain, and a cytoplasmic domain. ${ }^{46}$ The regulation of cell survival, cell cycle, axonal growth, and myelin formation have been considered to be the main functions of the p75NTR. ${ }^{47,48}$ It can cooperate with other receptors to form heterodimeric complexes. For instance, the interaction with the TrkB has been shown to increase the affinity of BDNF to its binding site, ${ }^{49}$ thus enhancing the cell survival. On the other hand, the interface with sortilin leads to the initiation of the apoptosis by pro-BDNF. ${ }^{50}$ Sortilin, as mentioned above, is another receptor that interacts with BDNF. It belongs to type-I transmembrane vacuolar protein-sorting 10 protein (Vps10p) domain containing receptors family. ${ }^{51}$ Sortilin operates as a coreceptor that regulates TrkB or $\mathrm{p} 75 \mathrm{NTR}$ expression in response to a pro-neurotrophin and initiates the apoptotic cascade. ${ }^{50}$ Also, it has been recently shown that the interaction of sortilin with Huntingtin-associated protein-1 causes the activation of intracellular protease furin, which, in turn, cleaves the pro-BDNF to a mature form. ${ }^{33}$

\section{BDNF-mediated signal transduction TrkB receptor}

Binding of BDNF to TrkB with picomolar affinity (Figure 1) induces the dimerization of the receptor and the autophosphorylation of the tyrosine residues in the juxtamembrane domain that creates the binding or docking sites for such molecules as Src-homology 2 domain containing transforming protein (Shc), Src-homology phosphatase 2 (Shp2), growth factor receptor-binding protein 2 (Grb2), and phospholipase $\mathrm{C} \gamma$ (PLC $\gamma) 1 .^{52}$ Further interaction of these molecules initiates the activation of various signaling cascades, which have been described in numerous reviews elsewhere. ${ }^{53-55}$ Here, this will be discussed superficially, in order to give a general overview of BDNF's action.

PLC $\gamma$ pathway (Figure 1) is mainly essential for synaptic plasticity. ${ }^{55}$ Phosphorylation of the tyrosine residue at position
816 causes PLC $\gamma$ to bind to this site in the juxtamembrane domain. Then, PLC $\gamma$ can hydrolyze phosphatidylinositol 4,5biphosphate $\left(\mathrm{PIP}_{2}\right)$ to form diacylglycerol (DAG) and inositol 1,4,5-trisphosphate $\left(\mathrm{IP}_{3}\right)$. IP 3 binds to the calcium $\left(\mathrm{Ca}^{2+}\right)$ ion channel of the endoplasmic reticulum, releasing $\mathrm{Ca}^{2+}$ into the cytoplasm. High intracellular $\mathrm{Ca}^{2+}$ initiates protein-kinase $\mathrm{C}$ (PKC) activation by DAG as well as activation of membrane transient receptors potential channels (TRPC) that, in turn, induce dendritic remodeling. ${ }^{56}$ Furthermore, released $\mathrm{Ca}^{2+}$ stimulates $\mathrm{Ca}^{2+} /$ calmodulin-dependent protein kinase 2 (CaMKII) or CAMKIV capable of phosphorylating the activating Ser-133 site of cyclic adenosine monophosphate (cAMP) response element-binding protein (CREB) either directly or via activation of downstream kinases p38 of mitogen-activated protein kinases (MAPK) superfamily. ${ }^{57}$ The CREB is welldocumented as a transcriptional factor involved in the neuronal plasticity, learning and memory, outgrowth of neuronal processes, induction of neurotrophic and neuroprotectant cellular programs, and regulation of circadian rhythms. ${ }^{58}$

Phosphoinositide 3-kinase (PI3K) pathway (Figure 1) is mostly crucial for the survival and proliferation of neuronal cells. ${ }^{59}$ Upon phosphorylation of the tyrosine domain at position 515, the adaptor protein Shc binds to this site and is able to interact with Grb2-associated-binding protein 1 (GAB1) that forms a docking site for PI3K (Figure 1). Then active PI3K binds to $\mathrm{PIP}_{2}$ and converts it to $\mathrm{PIP}_{3}$ leading to the activation of Akt, also known as protein kinase $\mathrm{B}$ (PKB), through phosphoinositide-dependent kinase-1 (PDK1) interaction. The proto-oncoprotein Akt binds with B-cell lymphoma 2 (Bcl-2) associated $\mathrm{X}$ protein $(\mathrm{Bax})^{60}$ increasing its proportion in the $\mathrm{Bcl}-2 / \mathrm{Bax}$ ratio leading to the antiapoptotic effect. Another signaling cascade of Akt involves the activation of mammalian target of rapamycin (mTOR), a high MW serinethreonine protein kinase that promotes protein synthesis in neuronal dendrites, initiating neurocyte growth, proliferation, and synaptic plasticity. ${ }^{61}$ Additionally, a recent study showed that the BDNF/mTOR pathway is also involved in the stabilization of memory traces, which is crucial for the long-term memory (LTM) formation. ${ }^{62}$

MAPK pathway is known to be important in neuronal cell growth, differentiation, protection, and release of neurotransmitters. ${ }^{63}$ The activation of this pathway involves recruitment of Shc with further interaction with Grb2. The formation of Grb 2/son of sevenless (SOS) complex results in the initiation of rat sarcoma (Ras) protein by the conversion of guanosine diphosphate to guanosine triphosphate (GTP) (Figure 1). Active Ras turns out to be able to bind the effector protein kinase rapid accelerated fibrosarcoma $B$ (B-Raf), which, in turn, phosphorylates mitogen-activated 


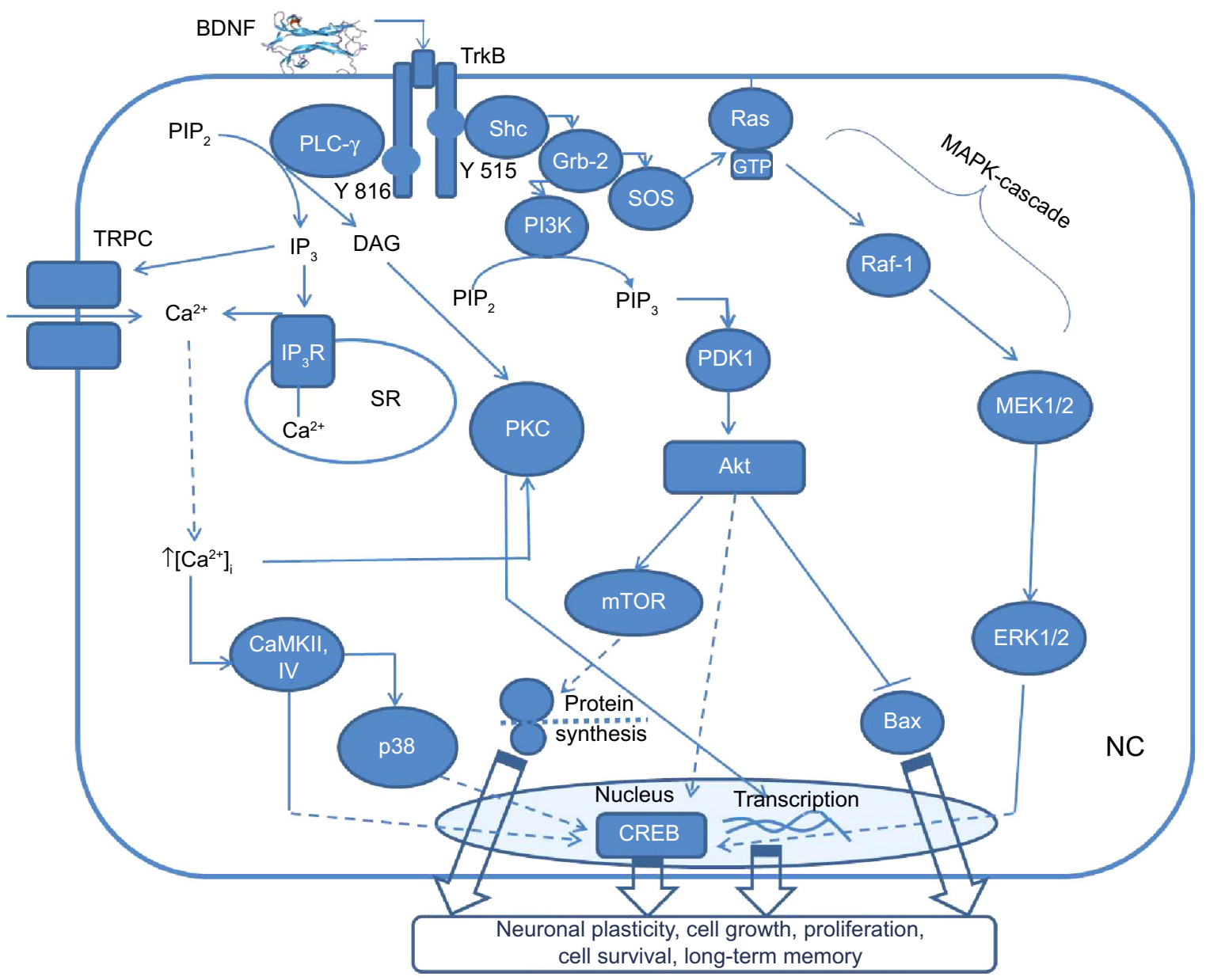

Figure I A general scheme, illustrating BDNF-TrkB signaling through three main pathways in the neuronal cell (NC).

Notes: PLC $\gamma$ pathway results in activation of neuronal plasticity and long-term memory formation via PKC, TRPC, and transcriptional factor CREB. Also PLC $\gamma$ activates inositol trisphosphate receptor $\left(\mathrm{IP}_{3} \mathrm{R}\right)$ via $\mathrm{IP}_{3}$ to release intracellular calcium $\left(\mathrm{Ca}^{2+}\right)$ from sarcoplasmatic reticulum (SR). PI3K-Akt pathway activates $C R E B$ and causes further downstream activation of $\mathrm{mTOR}$, which stimulates protein synthesis in neuronal dendrites leading to cell growth, proliferation, and synaptic plasticity. Also, PI3K-Akt pathway blocks Bax protein causing antiapoptotic action. Mitogen-activated protein kinases (MAPK) cascade results in activation of transcriptional factor CREB with further stimulation of cell growth, differentiation, protection, releasing of neurotransmitters, and memory formation.

Abbreviations: BDNF, brain-derived neurotrophic factor; TrkB, tropomyosin receptor kinase B; PLC $\gamma$, phospholipase C $\gamma$; PKC, protein-kinase C; TRPC, transient receptors potential channels; CREB, cyclic adenosine monophosphate response element-binding protein; Shc, Src-homology 2 domain containing transforming protein; Grb-2, growth factor receptor-binding protein 2; $\mathrm{IP}_{3}$, inositol triphosphate; $\mathrm{PIP}_{2}$, phosphatidylinositol 4,5-biphosphate; DAG, diacylglycerol; CaMKII, Ca ${ }^{2+} / \mathrm{calmodulin}$-dependent protein kinase 2; PI3K, phosphoinositide 3-kinase; PKB, protein kinase B; PDKI, phosphoinositide-dependent kinase-I; Bax, B-cell lymphoma 2 associated X protein; mTOR, mammalian target of rapamycin; SOS, son of sevenless; Ras, rat sarcoma; GTP, guanosine triphosphate; B-Raf, rapid accelerated fibrosarcoma B; ERK, extracellular signalregulated kinases.

protein kinase kinase (MEK) $1 / 2$ leading to the activation of extracellular signal-regulated kinases (ERK) $1 / 2$. Finally, the activated ERK $1 / 2$ influences the previously mentioned transcriptional factor CREB. ${ }^{64}$

\section{P75NTR and sortilin}

As described earlier in the "BDNF receptors" section, BDNF has a 1,000-fold lower affinity to pan-neurotrophin receptor $\mathrm{p} 75$ that interacts with TrkB enhancing its response to BDNF, thus promoting the cell survival..$^{65}$ The opposite action of p75NTR as a cell death receptor occurs when it forms the receptor complex with sortilin. ${ }^{50}$ Beside this, p75NTR causes axon degeneration when it forms a triple complex with neurite outgrowth inhibitory protein receptor
(NogoR) and leucine-rich repeat and Ig domain containing NogoR interacting protein 1 (LINGO-1). This complex promotes the suppression of axon growth involving three myelin-associated glycoproteins, specifically Nogo, myelinassociated glycoprotein, and oligodendrocyte-myelin glycoprotein. ${ }^{66}$ The signaling cascades, which follow the binding BDNF or pro-BDNF to p75NTR have been shown to promote the neurite outgrowth, proliferation, and apoptosis. ${ }^{67}$ All these pathways are set off after the binding of adaptor proteins to activated $\mathrm{p} 75 \mathrm{NTR}$, including neurotrophin receptor-interacting factor (NRIF), p75NTR interacting protein (NRAGE), p75NTR-associated death executor (NADE, NRH2), ${ }^{67}$ and TNF receptor-associated factors (TRAF) proteins. ${ }^{68}$ 
Jun-kinases signaling pathway (Figure 2) results in the activation of phosphoprotein $\mathrm{p} 53$ and apoptosis. In response to BDNF, p75NTR promotes Jun-kinases signaling pathway via interactions with NRAGE, TRAF6, and NRIF, stimulating the stress kinase c-Jun N-terminal kinase (JNK). The activation of Jun-kinases cascade involves the initiation of cell division control protein 42 (Cdc42), which, in turn, activates apoptosis signal regulated kinase 1 (ASK1). Additionally, a Jun-kinases kinase named MKK7 is shown to be a link between ASK1 and JNK. ${ }^{69} \mathrm{JNK}$ activation induces the phosphorylation of transcription factor c-Jun and tumor suppressor $\mathrm{p} 53,{ }^{70}$ resulting in upregulation of proapoptotic genes and caspases $^{71}$ that ultimately causes cell death. ${ }^{72,73}$

Nuclear factor kappa-light-chain-enhancer of activated $\mathrm{B}$ cells (NF-KB) signaling pathway (Figure 2) in contrast to the previous one is proven to be an antiapoptotic. ${ }^{74}$ Binding of the neurotrophin promotes the interaction between TRAF6 proteins and p75NTR cytoplasmic domain. Interleukin-1 receptor-associated kinase (IRAK) also binds to p75NTR forming a complex with TRAF6 that results in the activation of atypical PKC, which, in turn, phosphorylates nuclear factor of kappa light polypeptide gene enhancer in B-cells inhibitor (IKB) kinase- $\beta$ (IKK- $\beta$ ). ${ }^{55}$ IKK- $\beta$-mediated phosphorylation of IKB results in the translocation of NF- $\kappa B$ into the nucleus, where genes, induced by NF- $\mathrm{KB}$, promote cell survival or inhibition of the apoptosis. ${ }^{75}$

The signaling molecule ceramide (Figure 2) is a result of the activation of the sphingomyelin cycle. ${ }^{76}$ The role of the ceramide in neuronal cell signaling has yet been fully understood. ${ }^{77} \mathrm{But}$, it is well-known that ceramide influences Jun-kinases and NF- $\mathrm{kB}$ signaling pathways, promoting both apoptotic and prosurvival pathways. ${ }^{55}$

\section{BDNF as a therapeutic option for blindness}

In the year 2010, there were 32.4 million blind people and 191 million vision-impaired people worldwide. ${ }^{78}$ Diabetic retinopathy, age-related macular degeneration, and glaucoma are recognized to be the main diseases, which can lead to irreversible blindness. ${ }^{79}$ Various stimuli, like high intraocular pressure (IOP), blockage of axonal flow, and retinal ischemia may cause cellular damage in the retina ${ }^{80}$ Glaucoma, ${ }^{81}$ ischemia,${ }^{82}$ age-related macular degeneration, ${ }^{83}$ diabetic retinopathy, ${ }^{84}$ and optic neuritis ${ }^{85}$ are the potential contributors to retinal ganglion cells (RGCs) neurodegeneration and subsequent loss. It has been studied that survival of RGCs was enhanced by BDNF in vitro ${ }^{86}$ Moreover, at the retina, BDNF receptor, TrkB, has been found to be expressed by a number of cell types, namely, a subset of cone photoreceptors ${ }^{87}$ amacrine cells ${ }^{88}$ Muller glia, ${ }^{89}$ and RGCs. ${ }^{90}$ Therefore, in recent years, BDNF appears to be a major therapeutic strategy in vivo for ocular or systemic diseases that may lead to cellular damage in the retina. A variety of approaches associated with the delivery of BDNF to the posterior eye segment have been presented in Table 1 . $\mathrm{BRB}$, which has similar features with the BBB,${ }^{11}$ limits the movements of BDNF after systemic and periocular administration to the retina. On the other hand, anatomical features of the eye are known to circumvent the need for systemic administration by using relatively straightforward direct access to the retina, like intravitreal injection. This anatomical advantage avoids pharmacological challenges faced by BDNF delivery into the CNS, such as BBB penetration and degradation in the circulation.

Meanwhile, axotomy, as an animal model, has been extensively used to discover the survival of $\mathrm{RGCs}^{92}$ and BDNF signal transduction pathways. ${ }^{93,94}$ This model has been reported to be performed in rats, ${ }^{92,95,96}$ cats, ${ }^{97}$ mice, ${ }^{98}$ and hamsters. ${ }^{99}$ Apart from this, other animal models, used to establish the BDNF activity in the retina, include light damage, ${ }^{100}$ elevated intraocular pressure, ${ }^{101}$ potassium cyanide-induced retinal damage, ${ }^{102} \mathrm{~N}$-methyl-D-aspartate (NMDA) excitotoxicity, ${ }^{103}$ optic nerve trauma, ${ }^{97}$ anterior ischemic optic neuropathy, ${ }^{104}$ exploiting the dystrophic royal college of surgeons (RCS) rats strain ${ }^{105}$ and investigation of the normal retina development in young rats. ${ }^{106}$

\section{Direct BDNF delivery to the posterior eye segment Pure BDNF}

The first intravitreal injection of pure recombinant BDNF was made to the axotomized rats in doses of $0.1-0.15 \mu \mathrm{g} /$ rat/eye. ${ }^{107}$ It had shown substantial increase in survival of injured cells 3 weeks after lesion in comparison to control. However, it had been discovered that the single injections could only temporarily rescue RGCs from neuronal death (Table 1). Five weeks after injury, the level of surviving cells did not increase very much, showing the transient effect of BDNF single injection. Later, the multiple injections, as a simple and logical way to surmount this limitation, were demonstrated by Mansour-Robaey et al. ${ }^{92}$ Importantly, this study has detected the optimal dose, which is $5 \mu \mathrm{g}$ of BDNF/one rat's eye. As it turned out, the size of the animals is critical for dosing of BDNF, thus for mice, rats, young rats, and hamsters, the dose range was from 0.1 to $5 \mu \mathrm{g} / \mathrm{eye} / \mathrm{animal}$, whereas for cats, with the size of eye and vitreal volume comparable to those of primates, $30 \mu \mathrm{g}$ was chosen as an optimal dose (Table 1). Even though the volume of vitreal chamber in cat's eye is around $3 \mathrm{~mL}$, while 


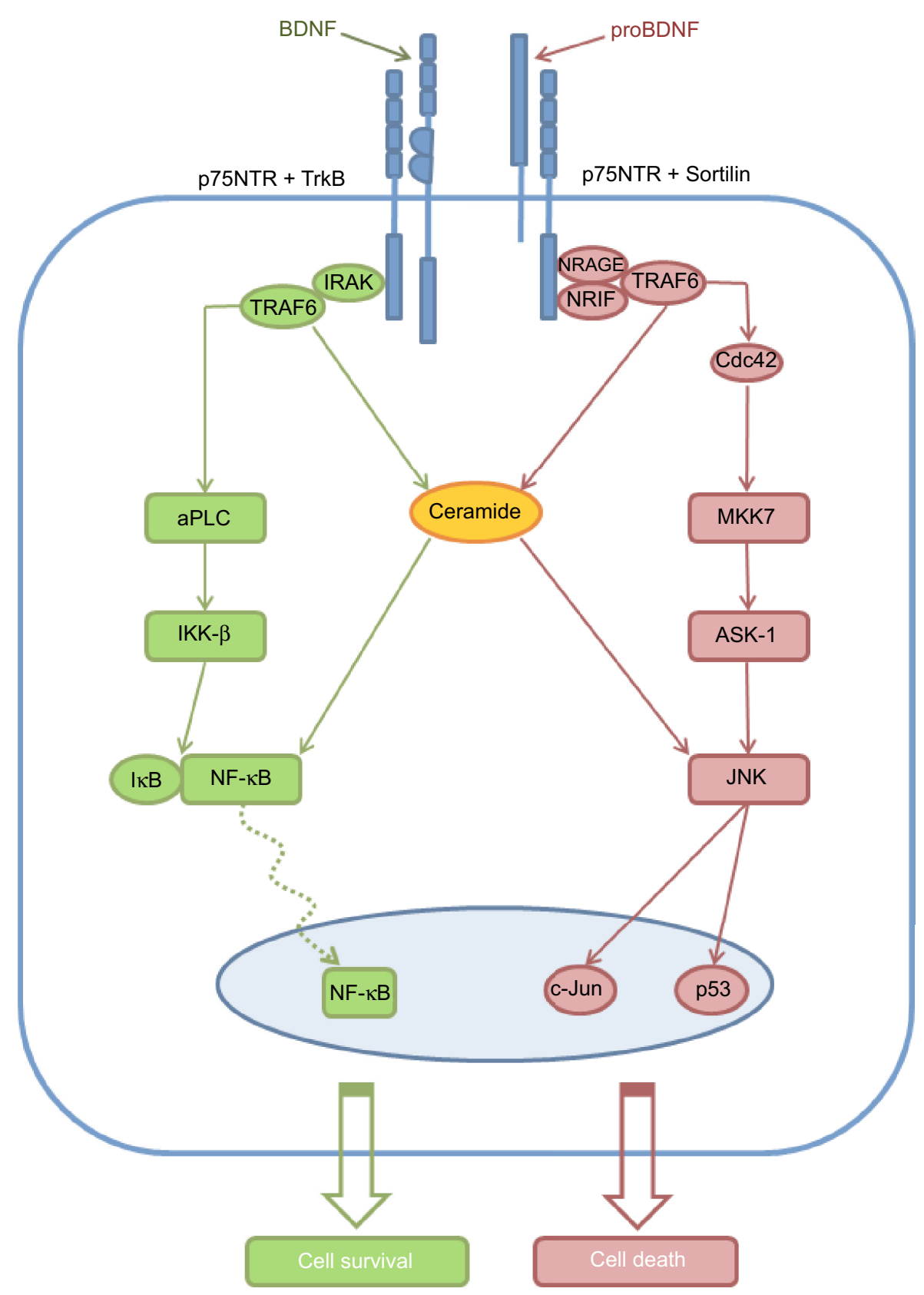

Figure 2 An overall scheme illustrating P75NTR signaling.

Notes: Heterodimerization with TrkB in response to BDNF action causes phosphorylation of IKB resulting in liberating of NF- $\mathrm{KB}$, which after translocation into the nucleus promotes gene transcription to support neuron survival. Oppositely, heterodimerization with sortilin in response to pro-BDNF induces activation of Jun-kinase signaling pathway resulting in activation of proapoptotic genes and caspases causing cell death. Signaling molecule ceramide takes part in both NF-KB and Jun-kinases signaling cascades. Abbreviations: BDNF, brain-derived neurotrophic factor; p75NTR, p75 neurotrophin receptor; TrkB, tropomyosin related kinase B; NRIF, neurotrophin receptorinteracting factor; NRAGE, P75NTR interacting protein; TRAF, tumor necrosis factor receptor-associated factor; Cdc42, cell division control protein 42; ASKI, apoptosis signal regulated kinase I; JNK, c-Jun N-terminal kinase; IRAK, interleukin-I receptor-associated kinase; aPKC, atypical protein kinase C; IкB, kappa light polypeptide gene enhancer in B-cells inhibitor; NF-KB, nuclear factor kappa-light-chain-enhancer of activated B cells; MKK7, mitogen-activated protein kinase kinase 7.

rat's eye is 60 -fold smaller $(0.05 \mathrm{~mL})$, the concentration of drug at the site of action appeared approximately the same $(\sim 0.01 \mu \mathrm{g} \mathrm{BDNF} / \mu \mathrm{L}$ of vitreal volume $) .{ }^{97}$ Moreover, LaVail et a ${ }^{108}$ compared the effectiveness of the intravitreal injection of the BDNF in concentrations of 1,2,5, and $10 \mathrm{mg} / \mathrm{mL}$ for both mice and rats, but the difference in volume of the injected solution was just 2 fold $(0.5$ and
$1 \mu \mathrm{L}$, respectively), while mice have in 6.6-fold smaller vitreal chamber than rats.

Although intravitreal injection of BDNF have been shown as a good strategy for the treatment of various ocular and systemic diseases, some important limitations have been observed. Chen and Weber ${ }^{97}$ displayed that at some doses, the increased levels of BDNF had resulted in 
Table I Different approaches of application of BDNF in the treatment of posterior eye segment degenerative diseases

\begin{tabular}{|c|c|c|c|c|}
\hline Author, year & Animal model & $\begin{array}{l}\text { Method administered/ } \\
\text { timing }\end{array}$ & Effect & Dosing \\
\hline \multicolumn{5}{|c|}{ Administration of purified protein } \\
\hline $\begin{array}{l}\text { Mey and Thanos, }{ }^{107} \\
1993\end{array}$ & Rat: axotomy & Intravitreous/single & $\begin{array}{l}\text { Transient survival of injured } \\
\text { RGCs }\end{array}$ & $\begin{array}{l}\text { BDNF } 50 \mathrm{ng} / 100 \mathrm{~g} \\
\text { body weight }\end{array}$ \\
\hline $\begin{array}{l}\text { Mansour-Robaey } \\
\text { et al, }{ }^{92} \text { I } 994\end{array}$ & Rat: axotomy & $\begin{array}{l}\text { Intravitreous/single vs multiple } \\
\text { (on day } 0,3,7 \text {, and } 10 \text { ) }\end{array}$ & $\begin{array}{l}\text { Multiple injections caused } \\
\text { better survival of RGCs in } \\
\text { comparison to single injection }\end{array}$ & BDNF $5 \mu \mathrm{g}$ \\
\hline $\begin{array}{l}\text { Unoki and La Vail,, }{ }^{197} \\
\text { 1994 }\end{array}$ & $\begin{array}{l}\text { Rat: pressure- } \\
\text { induced ischemia }\end{array}$ & $\begin{array}{l}\text { Intravitreous/single vs } \\
\text { multiple ( } 2 \text { days before } \\
\text { ischemic insult and } \\
4 \text { or } 5 \text { days after) }\end{array}$ & $\begin{array}{l}\text { Transient protection of the } \\
\text { retina after single injection, } \\
\text { but second injection of BDNF } \\
\text { prolonged the protective effect }\end{array}$ & BDNF I $\mu \mathrm{g}$ \\
\hline $\begin{array}{l}\text { Weibel et al, }{ }^{96} \\
1995\end{array}$ & $\begin{array}{l}\text { Young rat: } \\
\text { axotomy }\end{array}$ & $\begin{array}{l}\text { Intravitreous/single } \\
\text { vs multiple }\end{array}$ & $\begin{array}{l}\text { Positive effect of BDNF on the } \\
\text { survival of injured optic nerve } \\
\text { axons in comparison to other } \\
\text { neurotrophic factors }\end{array}$ & BDNF $0.1 \mu \mathrm{g}$ \\
\hline $\begin{array}{l}\text { Sawai et al, }{ }^{198} \\
1996\end{array}$ & Rat: axotomy & Intravitreous/single & $\begin{array}{l}\text { Injection of BDNF or NT-4/5 } \\
\text { improved axonal branch growth } \\
\text { within the retina, but injection of } \\
\text { NT-3 did not }\end{array}$ & BDNF $5 \mu \mathrm{g}$ \\
\hline $\begin{array}{l}\text { Peinado-Ramon } \\
\text { et al, }{ }^{199} \text { | } 996\end{array}$ & Rat: axotomy & Intravitreous/single & $\begin{array}{l}\text { Survival, and delaying the onset } \\
\text { of RGCs death }\end{array}$ & BDNF $5 \mu \mathrm{g}$ \\
\hline $\begin{array}{l}\text { Cellerino et al, }{ }^{106} \\
1998\end{array}$ & $\begin{array}{l}\text { Development of } \\
\text { rat retina }\end{array}$ & Intravitreous/multiple & $\begin{array}{l}\text { BDNF regulated the growth of } \\
\text { the retinal dopaminergic neurons }\end{array}$ & BDNF I $\mu g \times 3$ \\
\hline $\begin{array}{l}\text { LaVail et al, }{ }^{108} \\
1998\end{array}$ & $\begin{array}{l}\text { Rat/mouse: light } \\
\text { damage }\end{array}$ & Intravitreous/single & $\begin{array}{l}\text { Protection of the } \\
\text { photoreceptors } \\
\text { from degeneration }\end{array}$ & $\begin{array}{l}\text { Rat BDNF: I, } 5 \text {, } \\
10 \mu \mathrm{g} ; \text { mouse BDNF: } \\
0.5,2.5,5 \mu \mathrm{g}\end{array}$ \\
\hline $\begin{array}{l}\text { Ikeda et al, }{ }^{102} \\
1999\end{array}$ & $\begin{array}{l}\text { Rat: potassium } \\
\text { cyanide (KCN)- } \\
\text { induced retinal } \\
\text { damage }\end{array}$ & Intravitreous/single & $\begin{array}{l}\text { BDNF attenuated the inner } \\
\text { nuclear layer cell death }\end{array}$ & ${ }^{125} \mid-B D N F I \mu g$ \\
\hline $\begin{array}{l}\text { Cellerino et al, }{ }^{200} \\
1999\end{array}$ & $\begin{array}{l}\text { Development of } \\
\text { rat retina }\end{array}$ & Intravitreous/single & $\begin{array}{l}\text { BDNF activated NADPH- } \\
\text { diaphorase in dopaminergic } \\
\text { neurons and displaced amacrine } \\
\text { cells to the ganglion cell layer, } \\
\text { but did not protect them }\end{array}$ & BDNF I $\mu g$ \\
\hline $\begin{array}{l}\text { Kurokawa et al, }{ }^{201} \\
1999\end{array}$ & Rat: axotomy & Intravitreous/single & $\begin{array}{l}\text { Cell death in RGCs and the } \\
\text { caspase-2-positive cells were } \\
\text { lower }\end{array}$ & BDNF $5 \mu \mathrm{g}$ \\
\hline $\begin{array}{l}\text { Klöcker et al, }{ }^{93} \\
2000\end{array}$ & Rat: axotomy & $\begin{array}{l}\text { Intravitreous/multiple } \\
4,7 \text {, and } 10 \text { days after } \\
\text { axotomy }\end{array}$ & $\begin{array}{l}\text { Inhibition of PI3K did not } \\
\text { reduce the BDNF effects } \\
\text { on RGCs survival }\end{array}$ & BDNF $0.5 \mu \mathrm{g} \times 3$ \\
\hline $\begin{array}{l}\text { Kido et al, }{ }^{103} \\
2000\end{array}$ & $\begin{array}{l}\text { Rat: NMDA } \\
\text { excitotoxicity }\end{array}$ & Intravitreous/single & $\begin{array}{l}\text { BDNF of I and } 10 \mu \mathrm{g} \text { has } \\
\text { protective effects on retinal } \\
\text { damage }\end{array}$ & $\begin{array}{l}\text { BDNF } 0.1, I \text {, or } \\
10 \mu g\end{array}$ \\
\hline $\begin{array}{l}\text { Chen and Weber, }{ }^{97} \\
2001\end{array}$ & $\begin{array}{l}\text { Cat: optic nerve } \\
\text { trauma }\end{array}$ & $\begin{array}{l}\text { Intravitreous/single; } \\
\text { intravitreous/multiple }\end{array}$ & $\begin{array}{l}30 \mu \mathrm{g} \text { showed highest RGCs } \\
\text { survival, whereas high doses } \\
\text { showed low survival and } \\
\text { inflammation }\end{array}$ & $\begin{array}{l}\text { BDNF I5, 30, 60, } \\
90 \mu \mathrm{g} 30 \times 2,60 \times 2 \mu \mathrm{g}\end{array}$ \\
\hline $\begin{array}{l}\text { Chen and Weber, } 202 \\
2002\end{array}$ & Rat: axotomy & Intravitreous/single & $\begin{array}{l}\text { No significant effect on glial } \\
\text { fibrillary acidic protein or } \\
\text { glutamine synthetase expression }\end{array}$ & BDNF $5 \mu \mathrm{g}$ \\
\hline $\begin{array}{l}\text { Ota et al, }{ }^{203} \\
2002\end{array}$ & Rat: axotomy & Intravitreous/single & $\begin{array}{l}\text { Smaller change in soma } \\
\text { cell-size distribution }\end{array}$ & BDNF $5 \mu \mathrm{g}$ \\
\hline $\begin{array}{l}\text { Nakazawa et al, }{ }^{94} \\
2002\end{array}$ & Rat: axotomy & Intravitreous/single & $\begin{array}{l}\text { Both MAPK and PI3K-Akt } \\
\text { pathways involved in } \\
\text { neuroprotective signaling }\end{array}$ & BDNF I $\mu g$ \\
\hline $\begin{array}{l}\text { Krueger-Naug } \\
\text { et al, }{ }^{204} 2003\end{array}$ & Rat: axotomy & Intravitreous/single & $\begin{array}{l}\text { The expression of heat shock } \\
\text { protein } 27 \text { in RGCs was reduced }\end{array}$ & BDNF $5 \mu g$ \\
\hline
\end{tabular}


Table I (Continued)

\begin{tabular}{|c|c|c|c|c|}
\hline Author & Animal model & $\begin{array}{l}\text { Method administered/ } \\
\text { timing }\end{array}$ & Effect & Dosing \\
\hline $\begin{array}{l}\text { Chen and Weber, }{ }^{109} \\
2004\end{array}$ & Rat: nerve crush & Intravitreous/single & $\begin{array}{l}\text { BDNF decreased in TrkB.FL } \\
\text { (both mRNA and protein) }\end{array}$ & BDNF $5 \mu \mathrm{g}$ \\
\hline $\begin{array}{l}\text { Lee et al, }{ }^{205} \\
2005\end{array}$ & Rat: axotomy & Intravitreous/single & $\begin{array}{l}\text { BDNF affected the expression } \\
\text { of anti-tyrosine hydroxylase } \\
\text { immunoreactivity }\end{array}$ & BDNF $5 \mu g$ \\
\hline $\begin{array}{l}\text { Chen et al, } \\
2012\end{array}$ & $\begin{array}{l}\text { Mouse: light } \\
\text { damage }\end{array}$ & Intravitreous/single & $\begin{array}{l}\text { Dose and time-dependent c-Jun } \\
\text { expression in the retina }\end{array}$ & BDNF $0.1 \mu g ; 0.2 \mu g$ \\
\hline $\begin{array}{l}\text { Galindo-Romero } \\
\text { et al, }{ }^{98} 2013\end{array}$ & Mouse: axotomy & Intravitreous/single & $\begin{array}{l}\text { Neuroprotective effect on the } \\
\text { axotomized RGCs }\end{array}$ & BDNF $2.5 \mu \mathrm{g}$ \\
\hline \multicolumn{5}{|c|}{ Administration of purified protein in combinations } \\
\hline $\begin{array}{l}\text { Klöcker et al, }{ }^{116} \\
1998\end{array}$ & Rat: axotomy & Intravitreous/single & $\begin{array}{l}\text { Single BDNF treatment rescued } \\
27 \% \text { of the RGCs transiently. } \\
\text { Combined treatment of BDNF } \\
\text { with free radical scavenger } \\
\text { N-tert-butyl-(2-sulfophenyl)- } \\
\text { nitrone (S-PBN) improved } \\
\text { survival up to } 68 \% \text {, and with } \\
\text { NOS-inhibitor } N \text { - } \omega \text {-nitro-L- } \\
\text { argininemethylester (L-NAME) - } \\
\text { up to } 55 \%\end{array}$ & $\begin{array}{l}\text { BDNF 0.2, 0.5, } 2 \mu \mathrm{g} \\
+ \text { L-NAME, S-PBN }\end{array}$ \\
\hline $\begin{array}{l}\text { Yan et al, }{ }^{207} \\
1999\end{array}$ & Rat: axotomy & $\begin{array}{l}\text { Intravitreous/multiple } \\
\text { I, } 7 \text { days }\end{array}$ & $\begin{array}{l}\text { Combination GDNF and BDNF } \\
\text { showed better protection than } \\
\text { each factor individually }\end{array}$ & $\begin{array}{l}0.5 \mu \mathrm{g} \text { GDNF }+0.5 \\
\mu \mathrm{g} \text { BDNF } \times 2 ; \\
\mathrm{I} .0 \mu \mathrm{g} \text { GDNF }+1.0 \mu \mathrm{g} \\
\mathrm{BDNF} \times 2\end{array}$ \\
\hline $\begin{array}{l}\text { Ko et al, }{ }^{101} \\
2000\end{array}$ & Rat: high IOP & $\begin{array}{l}\text { Intravitreous/multiple } 5,13 \text {, } \\
21 \text {, and } 29 \text { days after IOP } \\
\text { elevation }\end{array}$ & $\begin{array}{l}\text { Combination of BDNF and } \\
\text { S-PBN substantially improved } \\
\text { survival of RGCs up to } 90.1 \%\end{array}$ & $\begin{array}{l}\text { BDNF } 0.5 \mu g \times 4 \\
\text { BDNF } 1.0 \mu g \times 4 \\
\text { BDNF } 0.5 \mu g+ \\
\text { S-PBN } \times 4 \\
\text { BDNF } 1.0 \mu g+ \\
\text { S-PBN } \times 4\end{array}$ \\
\hline $\begin{array}{l}\text { Koeberle and Ball, }{ }^{113} \\
2002\end{array}$ & Rat: axotomy & Intravitreous/single & $\begin{array}{l}\text { Neurturin, GDNF, and BDNF } \\
\text { had different cellular targets in } \\
\text { the retina to enhance RGCs } \\
\text { survival }\end{array}$ & $\begin{array}{l}\text { BDNF } 0.05,0.25, \\
0.5, \text { I } .0,2.5 \mu g \\
\text { I.0 } . \mathrm{g} \text { neurturin } \\
+1.0 \mu \mathrm{g} \text { BDNF } \\
\text { I.0 } \mathrm{gg} \text { GDNF + I.0 } \\
\mu \mathrm{g} \text { BDNF }\end{array}$ \\
\hline $\begin{array}{l}\text { Watanabe et al, }{ }^{114} \\
2003\end{array}$ & Cat: axotomy & Intravitreous/single & $\begin{array}{l}\text { Combined injection of BDNF, } \\
\text { CNTF, and forskolin (raises } \\
\text { intracellular concentration of } \\
\text { cAMP) resulted in a } 4.7 \text {-fold } \\
\text { increase of surviving increase of } \\
\beta \text {-cells of RGCs }\end{array}$ & $\begin{array}{l}\text { BDNF } 0.5, \text { I } \mu g \\
\text { BDNF I } \mu g+ \\
\text { CNTF I } \mu g+0.1 \mathrm{mg} \\
\text { forskolin }\end{array}$ \\
\hline $\begin{array}{l}\text { Tropea et al, }{ }^{115} \\
2003\end{array}$ & $\begin{array}{l}\text { Long-Evans rats: } \\
\text { retina lesion }\end{array}$ & $\begin{array}{l}\text { Intravitreous/single; osmotic } \\
\text { minipump }\end{array}$ & $\begin{array}{l}\text { BDNF in a combination } \\
\text { with chondroitinase } A B C \\
(C-A B C) \text {, which promotes CNS } \\
\text { regeneration via degradation } \\
\text { of chondroitin sulfate } \\
\text { proteoglycans side chains, results } \\
\text { in reinnervation of the collicular } \\
\text { scotoma by unlesioned RGCs } \\
\text { axons }\end{array}$ & $\begin{array}{l}\text { BDNF } 10 \mu g+ \\
\text { C-ABC }\end{array}$ \\
\hline $\begin{array}{l}\text { Zhang et al, } \\
2005\end{array}$ & $\begin{array}{l}\text { Hamster: } \\
\text { axotomy }\end{array}$ & Intravitreous/single & $\begin{array}{l}\text { Protection RGCs and increasing } \\
\text { NOS activity by BDNF }\end{array}$ & $\begin{array}{l}\text { BDNF I. } 25,5 \mu \mathrm{g} \text { or } \\
\text { BDNF + CNTF }\end{array}$ \\
\hline $\begin{array}{l}\text { Fu et al, }{ }^{\prime 12} \\
2009\end{array}$ & Rat: high IOP & Intravitreous/single & Long-term protection for RGCs & $\begin{array}{l}\text { BDNF I } \mu g+ \\
\text { LINGO-I-Fc }\end{array}$ \\
\hline $\begin{array}{l}\text { Weber et al, }{ }^{117} \\
2010 \text {; Weber and } \\
\text { Harman, }{ }^{208} 2013\end{array}$ & $\begin{array}{l}\text { Cat: optic nerve } \\
\text { trauma }\end{array}$ & $\begin{array}{l}\text { Intravitreous/single; osmotic } \\
\text { minipump into brain vision } \\
\text { cortex } 14,28 \text { day }\end{array}$ & $\begin{array}{l}\text { Treatment eye }+ \text { cortex animals } \\
\text { showed better RGCs survival }\end{array}$ & $\begin{array}{l}\text { BDNF } 90 \mu g ; 12.6 \text {, } \\
25.2 \mu \mathrm{g}\end{array}$ \\
\hline
\end{tabular}


Table I (Continued)

\begin{tabular}{|c|c|c|c|c|}
\hline Author & Animal model & $\begin{array}{l}\text { Method administered/ } \\
\text { timing }\end{array}$ & Effect & Dosing \\
\hline $\begin{array}{l}\text { Goldenberg-Cohen } \\
\text { et al, }{ }^{133} 2014\end{array}$ & $\begin{array}{l}\text { Mouse: anterior } \\
\text { ischemic optic } \\
\text { neuropathy }\end{array}$ & Intravitreous/single & $\begin{array}{l}\text { Enhancing of neuroglial } \\
\text { differentiation of the RGCs }\end{array}$ & BDNF $5 \mu \mathrm{g}+\mathrm{BMSCs}$ \\
\hline \multicolumn{5}{|c|}{ Viral mediated BDNF delivery systems } \\
\hline $\begin{array}{l}\text { Di Polo et al, }{ }^{121} \\
1998\end{array}$ & Rat: axotomy & Intravitreous/single & $\begin{array}{l}\text { Ad.BDNF increased survival of } \\
\text { RGCs in } 4-5 \text { fold in comparison } \\
\text { with pure BDNF }\end{array}$ & $\begin{array}{l}\text { BDNF } 5 \mu g \\
\text { Ad.BDNF }\end{array}$ \\
\hline Mo et al, ${ }^{125} 2002$ & Rat: axotomy & $\begin{array}{l}\text { Electroporation of BDNF } \\
\text { gene to RGCs }\end{array}$ & $\begin{array}{l}\text { Protection axotomized RGCs } \\
\text { against apoptosis }\end{array}$ & BDNF gene \\
\hline Martin et al, ${ }^{124} 1996$ & Rat: high IOP & Intravitreous/single & Protection of RGC & AAV-BDNF-WPRE \\
\hline $\begin{array}{l}\text { Schuettauf et al, }{ }^{123} \\
2004\end{array}$ & $\begin{array}{l}\text { Rat: NMDA } \\
\text { excitotoxicity }\end{array}$ & Intravitreous/multiple & Retinal cell survival & AAV2 $3 \mu \mathrm{L} \times 3$ \\
\hline $\begin{array}{l}\text { Gauthier et al, }{ }^{122} \\
2005\end{array}$ & Rat: light damage & Intravitreous/single & $\begin{array}{l}\text { BDNF gene delivery enhanced } \\
\text { the survival and structural } \\
\text { integrity of damaged } \\
\text { photoreceptors }\end{array}$ & $\begin{array}{l}\text { BDNF } 5 \mu g \text { or } 5 \mu \mathrm{L} \\
\text { AAV }\end{array}$ \\
\hline Wang et al, ${ }^{209} 2009$ & Rabbit: high IOP & Intravitreous/single & Protecting the retinal structure & $10 \mu \mathrm{L}$ AAV \\
\hline Wan, ${ }^{210} 2010$ & $\begin{array}{l}\text { Rat: } \\
\text { streptozotocin } \\
\text { induced diabetes }\end{array}$ & Intravitreous/single & $\begin{array}{l}\text { Increase in tyrosine hydroxylase } \\
\text { and density of retinal } \\
\text { dopaminergic amacrine cells }\end{array}$ & $5 \mu \mathrm{L}$ AAV \\
\hline Ren et al, ${ }^{127} 2012$ & Rat: high IOP & Intravitreous/single & $\begin{array}{l}\text { Sustained rescue of RGCs and } \\
\text { visual function }\end{array}$ & $\begin{array}{l}\text { BDNF } 0.5 \mu g+ \\
\text { AAV-BDNF }\end{array}$ \\
\hline \multicolumn{5}{|c|}{ Cell-based BDNF delivery systems } \\
\hline Lawrence, ${ }^{105} 2004$ & $\begin{array}{l}\text { Dystrophic } \\
\text { Royal College } \\
\text { of Surgeons } \\
\text { rats (animal } \\
\text { with genetically } \\
\text { transmitted } \\
\text { progressive } \\
\text { retinal } \\
\text { dystrophy) }\end{array}$ & $\begin{array}{l}\text { Transplantation into the } \\
\text { subretinal space }\end{array}$ & $\begin{array}{l}\text { Preserving photoreceptors from } \\
\text { the cell death }\end{array}$ & $\begin{array}{l}\text { SCTM4I-BDNF } \\
\text { Schwann Cell Line; } \\
\text { SCTM4I-GDNF } \\
\text { Schwann Cell Line }\end{array}$ \\
\hline Abe et al, ${ }^{132} 2008$ & $\begin{array}{l}\text { Rat: retinitis } \\
\text { pigmentosa }\end{array}$ & $\begin{array}{l}\text { Transplantation into the } \\
\text { subretinal space/topical } \\
\text { doxycycline }\end{array}$ & $\begin{array}{l}\text { BDNF expression possible to } \\
\text { be controlled by doxycycline } \\
\text { (DOX) for photoreceptors' } \\
\text { protection }\end{array}$ & $\begin{array}{l}\text { Retinal pigment } \\
\text { epithelial cell line } \\
\text { that can express } \\
\text { BDNF by exposure } \\
\text { to DOX (Tet- } \\
\text { BDNF-RPE) }\end{array}$ \\
\hline Zhou et al, ${ }^{130} 2009$ & Rat: normal & $\begin{array}{l}\text { Intravitreous subretinal/ } \\
\text { single }\end{array}$ & $\begin{array}{l}\text { BDNF can promote neural } \\
\text { stem cells (NSCs) migration and } \\
\text { differentiation into neural cells }\end{array}$ & $\begin{array}{l}\text { I0 } \mu \mathrm{L} \text { NSC-BDNF } \\
\text { suspension }\left(10^{5} \text { cells }\right)\end{array}$ \\
\hline $\begin{array}{l}\text { Zhang and Wang, }{ }^{128} \\
2010\end{array}$ & $\begin{array}{l}\text { Rat: retinitis } \\
\text { pigmentosa }\end{array}$ & $\begin{array}{l}\text { Intraocular transplantation/ } \\
2 \text { weeks }\end{array}$ & $\begin{array}{l}\text { Inhibition of photoreceptor } \\
\text { apoptosis and slowing down } \\
\text { retinal damage }\end{array}$ & $\begin{array}{l}5 \mu \mathrm{L} \text { BMSC-BDNF } \\
\text { suspension }\left(5 \times 10^{4}\right. \\
\text { cells })\end{array}$ \\
\hline Park et al, ${ }^{129} 2012$ & Rat: axotomy & $\begin{array}{l}\text { Subretinal or intravitreal/ } \\
4 \text { weeks }\end{array}$ & $\begin{array}{l}\text { Increased BDNF mRNA and } \\
\text { protein expressions }\end{array}$ & $\begin{array}{l}20 \mu \mathrm{L} \text { rat } \\
\text { bone marrow } \\
\text { mesenchymal stem } \\
\text { cells (rMSC)-BDNF } \\
\left(3 \times 10^{5} \text { cells) }\right.\end{array}$ \\
\hline
\end{tabular}

Abbreviations: BDNF, brain-derived neurotrophic factor; RGCs, retinal ganglion cells; NT, neurotrophin; NMDA, N-methyl-D-aspartate; MAPK, mitogen-activated protein kinases; PI3K-Akt, phosphoinositide 3-kinase; GDNF, glial cell-derived neurotrophic factor; IOP, intraocular pressure; CNTF, ciliary neurotrophic factor; cAMP, cyclic adenosine monophosphate; C-ABC, chondroitinase ABC; CNS, central nervous system; NOS, nitric oxide synthase; LINGO-I, leucine rich repeat and immunoglobulin domain containing NogoR interacting protein I; NogoR, neurite outgrowth inhibitory protein receptor; BMSC, bone marrow stem cell; AAV, adeno-associated virus; DOX, doxycycline; NSCs, neural stem cells; rMSC, rat bone marrow mesenchymal stem cells; WPRE, woodchuck hepatitis posttranscriptional regulatory element; Ad.BDNF, adenovirus vector containing BDNF.

less neuronal survival. They also revealed that continuous application of BDNF intravitreally led to a decrease in the TrkB.FL receptors in rat retina, but not the "truncated" forms. ${ }^{109}$ They concluded that BDNF limits its own long-term neuroprotective efficacy by initiating downregulation of its TrkB receptor. Consequently, it is possible to assume that BDNF acts in a dose-dependent manner, however, multiple applications do not inevitably have an additive effect on 
RGCs survival. Furthermore, the safety profile of intravitreal injections, which depends on the surgical technique, the risk of cataract and retinal ischemia, as well as endophthalmitis, appears to be the major limitation of multiple injections. ${ }^{110}$ Therefore, in order to overcome difficulties with BDNF short half-life, dosing, and undesirable effects of multiple injections, other methods of BDNF delivery have been explored for long-term maintenance. One of them was a proposal to use hyaluronic acid aqueous solution of BDNF instead of conventional phosphate buffered saline or Hank's balanced salt solutions. BDNF was dissolved in $0.5 \%$ hyaluronic acid aqueous solution, resulting in a long-acting $1 \mathrm{mg} / \mathrm{mL}$ BDNF solution with sustained release of BDNF for $\sim 1$ week. ${ }^{111}$ In this study, long-acting BDNF improved the differentiation of the hippocampus-derived neural stem cells embedded into the developing rat retina in comparison to BDNF dissolved in Dulbecco's phosphate buffered saline.

\section{Combinations with BDNF}

The usage of combinations of BDNF with other growth factors or biological molecules (Table 1) has been proven to prolong half-life, ${ }^{112}$ increase effectiveness, ${ }^{113,114}$ enhance sprouting, ${ }^{115}$ and reduce side effects. ${ }^{116}$ Of interest, Weber et $\mathrm{al}^{117}$ have demonstrated that BDNF improves the survival of RGCs after optic nerve injury, as well as appearing to be a key factor in the protection of structure and visual function of ganglion cells. In this study, cat's eye with a crushed nerve was treated by BDNF $(90 \mu \mathrm{g})$ intravitreally, while an infusion cannula was connected to an osmotic minipump to deliver the BDNF ( $100 \mu \mathrm{L}$ of $0.3 \mu \mathrm{g} / \mu \mathrm{L}$ solution) into the visual thalamus. Such a combination substantially enriched the survival of RGCs and preserved central visual function.

\section{Viral mediated BDNF delivery}

To achieve stable and long-lasting transduction of retinal cells, researchers have utilized gene therapy by using viral vectors (Table 1). Among them, adeno-associated virus (AAV) was considered to be the most appropriate viral vector for gene therapy due to its sustained expression ${ }^{118}$ and safety. ${ }^{119}$ Furthermore, a research had shown that intravitreal injection of adenovirus (Ad) vector containing BDNF had resulted in the transduction of the retinal Muller cells, which then began to secrete Ad-mediated BDNF. ${ }^{120}$ Muller cells are essential for the maintenance and function of RGCs, moreover, they span across the entire sickness of the retina. Meanwhile, Di Polo et $\mathrm{al}^{121}$ reported a persistent expression of Ad-mediated BDNF by transduced Muller cells which had promoted survival of axotomized RGCs, but not for long-term. Next, Gauthier et al ${ }^{122}$ showed that BDNF gene transfer by AAV to Muller cells had served as a promising strategy to protect photoreceptors from light-induced retinal degeneration. Another study that explored the possibility of using recombinant AAV serotype 2 (AAV2) to deliver BDNF, revealed that this virus was able to provide efficient transduction of ganglion cells rather than Muller cells. ${ }^{123}$ Furthermore, Martin et al ${ }^{124}$ suggested the incorporation of woodchuck hepatitis posttranscriptional regulatory element (WPRE) in AAV-BDNF to facilitate transfection of neurons in rats' RGCs. It has also been reported that electroporation was utilized to deliver $B D N F$ gene into the RGCs. ${ }^{125}$ Such transport may decrease unwanted effects of the intravitreal injection technique, and BDNF cDNA can be delivered into RGCs without detectable damage to the RGCs. Although cells transduced by Ad show a more sustained release of BDNF within the posterior eye segment in comparison with a single intravitreal administration of pure BDNF protein, the onset of gene expression appears to be the major limitation for the usage of viral vectors. ${ }^{126}$ On the other hand, the combination of gene therapy with intravitreal injection of BDNF can compensate for the slow onset of viral-mediated expression. One study found that the combination of BDNF with AAV-BDNF had increased amount of survived RGCs by up to $97.4 \%$, which was greater than using AAV-BDNF alone. ${ }^{127}$

\section{Cell-based BDNF delivery}

The employment of stem cells (SCs) to transfer specific genes has been proposed as an alternative to the viral gene delivery approach (Table 1). ${ }^{105,128-130}$ The essential benefits of SCs are their extensive survival and the possibility to create cell and stem cell-based delivery systems for diverse therapeutics. ${ }^{131}$ It has been shown that bone marrow stem cells (BMSCs) transplanted into the subretinal space can express BDNF, thus executing trophic and protective effects on light-damaged rats' retinas. ${ }^{128}$ In addition, one study established a positive effect of usage of retinal-pigment epithelial cells carrying vectors transduced with the gene of a BDNF that were transplanted into the subretinal space of rats. This vector, which included a tetracycline-responsive element (TRE) and the cDNA of BDNF enabled upregulation of the expression of BDNF through the exposure of Tet-BDNF-RPE cells by topically applied doxycycline. ${ }^{132}$ Another study suggested that the usage of genetically modified Schwann cell lines would enhance the release of several growth factors. ${ }^{105}$ The combination of BMSCs with BDNF has been shown to promote differentiation of primitive cells derived from the bone marrow to the glial cells and neurons. ${ }^{133}$ Park et al ${ }^{129}$ 
applied a retroviral vector carrying rats' $B D N F$ cDNA to transduce rat bone marrow mesenchymal stem cells (rMSCs). After intravitreal or subretinal injection of modified rMSCs, the incorporation of the cells into the retina with further production of BDNF was detected. It is important to note that these methods present complications of subretinal injection technique, such as retinal folding and splitting, as well as rejection, accidental tumor growth, proliferative vitreoretinopathy, and choroidal neovascularization. ${ }^{134}$

\section{Nanoparticulate delivery}

Ophthalmic drug delivery via nanoparticulate systems has the potential of being a great discovery as such systems accomplish the four important criteria of ophthalmic drug delivery, namely, improved drug permeation, low toxicity, controlled sustained drug release, and selective drug targeting. ${ }^{135}$ Despite numerous promising results of using liposomes, solid lipid nanoparticles, polymeric nanoparticles, polymeric nanomicelles, and nanoemulsions for the treatment of posterior eye segment, the application of BDNF has not been published yet. ${ }^{136}$ On the other hand, a similar approach has been reported where intravitreal injection of the gelatin nanoparticles (NPs) with basic fibroblast growth factor (bFGF) was used for the treatment of photoreceptor degeneration in dystrophic RCS rats. ${ }^{137}$

\section{BDNF as a therapeutic option for deafness}

Hearing loss has affected over 360 million people worldwide, ${ }^{138}$ causing substantial burden for the economy, and has a high impact on quality of life and causes emotional distress. ${ }^{139}$ The existing conventional therapy for patients with injured hair cells (HCs) leading to hearing loss is a cochlear implant (CI) auditory prosthesis. CI electrodes directly stimulate spiral ganglion cells (SGCs) soma and probably their central axons, delivering partial restoration of sensory organ function in patients. ${ }^{140}$ In such cases, the maximal preservation of the population of SGCs becomes essential because severe SGC degeneration constrains the effectiveness of hearing rehabilitation by a CI. BDNF has been shown to take part in both the development and the maintenance of SGCs. ${ }^{141}$ Besides, BDNF has also been well-documented to be expressed by $\mathrm{HCs}$, as well as by supporting cells of the organ of Corti. ${ }^{142}$ Obviously, the damage of HCs or supporting cells in the auditory epithelium leads to a decrease in BDNF expression, causing degenerative changes in SGCs. ${ }^{143}$ Therefore, BDNF has a major place within different therapeutic approaches of deafness treatment (Table 2). However, systemic application of BDNF as a treatment for hearing loss was not very effective as it has short half-life, poor pharmacokinetics, and high risk of unwanted effects of high dose.

Furthermore, BCB is well-known to be critical in restricting the passage of large molecular weight substances into perilymph. The protein concentration in perilymph is $\sim 1 / 20$ that of blood. ${ }^{17}$ Of interest, protein penetration is about ten times higher than that of cerebrospinal fluid and four times higher than that of aqueous humor. ${ }^{144}$ Based on this, the delivery of pure BDNF from the systemic circulation into the inner ear should be easier than into the retina or brain, however, it still remains a challenge. In addition, the anatomical features do not allow large proteins to easily bypass this barrier using local direct injection, like intravitreal injection, as the organ of Corti is located inside the dense otic capsule of the temporal bone thus, limiting straight access. Direct drug delivery to patients using intratympanic delivery or diffusion through the round window membrane (RWM) or via cochleostomy, across the stapes footplate, or the endolymphatic sac seems to be a challenging task. ${ }^{145}$ Beside this, there are two advantages of such anatomical structures: first, the peri- and endolymphatic fluids provide a means for the distribution of BDNF throughout the whole cochlea and, second, BDNF delivered to the inner ear will not reach the systemic circulation, therefore, reducing adverse reactions to the organism. ${ }^{146}$

Many experimental models have been presented to cause hearing loss. Traditionally, the combination of aminoglycosides and diuretics is considered to be a classical one. ${ }^{147}$ Systemic administration of gentamicin, kanamycin or neomycin, and furosemide or etacrynic acid has been widely used by different researchers for producing loss of SGCs (Table 2). Besides this, other experimental models of deafness include, intraperitoneal injection of cisplatin, ${ }^{148}$ noise exposure, ${ }^{149}$ or exploiting of deaf Pou $4 f 3$ mutant mice. ${ }^{143}$ Although guinea pigs were established to be the most suitable animals for the experimental deafness, cats, rats, chinchillas, mice, and pigeons were also used (Table 2).

\section{Direct BDNF delivery into the inner ear Pure BDNF}

One of the most popular approaches to deliver BDNF into the inner ear is the implantation of osmotic minipump into scala tympani (Table 2). The main benefit of the mini-osmotic pump is that it allows regulated duration of the infusion of therapeutics from days to weeks, whereas injections offer discrete infusions and are followed by latent periods. Additionally, the opportunity to put in new full drug reservoir instead of consumed one by a 
Table 2 Different approaches of application of BDNF in the treatment of inner ear degenerative diseases

\begin{tabular}{|c|c|c|c|c|}
\hline Author, year & Animal model & $\begin{array}{l}\text { Method of administration/ } \\
\text { timing/dosing }\end{array}$ & Effect & Total dose \\
\hline \multicolumn{5}{|c|}{ Administration of purified protein } \\
\hline \multicolumn{5}{|c|}{ Implanted osmotic minipump (single) } \\
\hline $\begin{array}{l}\text { Miller et al, }{ }^{153} \\
1997\end{array}$ & $\begin{array}{l}\text { Guinea pigs: kanamycin }(400 \mathrm{mg} / \mathrm{kg}) \\
\text { and ethacrynic acid }(40 \mathrm{mg} / \mathrm{kg})\end{array}$ & 14 days/BDNF (50 ng/mL) & $\begin{array}{l}\text { Statistically significant } \\
\text { enhanced SGCs survival }\end{array}$ & BDNF 8.4 ng \\
\hline $\begin{array}{l}\text { Ruan et al, }{ }^{152} \\
1999\end{array}$ & $\begin{array}{l}\text { Guinea pigs: kanamycin } \\
(400 \mathrm{mg} / \mathrm{kg})\end{array}$ & $\begin{array}{l}15,30,60 \text { days/BDNF } \\
(100 \mu \mathrm{g} / \mathrm{mL})\end{array}$ & $\begin{array}{l}\text { Protective effect on HCs was } \\
\text { observed at } 30 \text { days, but not } \\
\text { at } 15 \text { and } 60 \text { days }\end{array}$ & $\begin{array}{l}\text { BDNF } 9 \mu \mathrm{g} \\
\text { BDNF } 18 \mu \mathrm{g} \\
\text { BDNF } 36 \mu \mathrm{g}\end{array}$ \\
\hline $\begin{array}{l}\text { Shoji et al, }{ }^{149} \\
2000\end{array}$ & $\begin{array}{l}\text { Guinea pigs: } 5 \text {-hour noise } \\
\text { exposure ( } 4 \mathrm{kHz} \text { octave band } \\
\text { noise, II } 15 \mathrm{~dB} \text { sound pressure } \\
\text { level) }\end{array}$ & $\begin{array}{l}\text { I } 2 \text { days/BDNF } \\
(\mathrm{I} \mu \mathrm{g} / \mathrm{mL} ; 10 \mu \mathrm{g} / \mathrm{mL})\end{array}$ & $\begin{array}{l}\text { BDNF did protect the } \\
\text { sensory epithelium }\end{array}$ & $\begin{array}{l}\text { BDNF } 0.144 \mu \mathrm{g} \\
\mathrm{I} .44 \mu \mathrm{g}\end{array}$ \\
\hline $\begin{array}{l}\text { Gillespie et al, }{ }^{155} \\
2003\end{array}$ & $\begin{array}{l}\text { Guinea pigs: kanamycin sulfate, } \\
400 \mathrm{mg} / \mathrm{kg} \text { + furosemide } \\
100 \mathrm{mg} / \mathrm{kg}\end{array}$ & $\begin{array}{l}28 \text { days/BDNF } \\
(62.5 \mu \mathrm{g} / \mathrm{mL})\end{array}$ & $\begin{array}{l}\text { SGCs survival is increased; } \\
\text { decrease in SGCs survival } \\
\text { after cessation of treatment }\end{array}$ & BDNF $10 \mu \mathrm{g}$ \\
\hline $\begin{array}{l}\text { McGuinness and } \\
\text { Shepherd, }{ }^{21} 2005\end{array}$ & $\begin{array}{l}\text { Rats: gentamicin, } 350 \mathrm{mg} / \mathrm{kg}+ \\
\text { furosemide, } 175 \mathrm{mg} / \mathrm{kg}\end{array}$ & $\begin{array}{l}28 \text { days/BDNF } \\
(5.4 \mu \mathrm{g} / \mathrm{mL})\end{array}$ & Significant rescue of SGCs & BDNF I.35 $\mu \mathrm{g}$ \\
\hline $\begin{array}{l}\text { Radeloff and } \\
\text { Smolders, }{ }^{151} \\
2006\end{array}$ & $\begin{array}{l}\text { Adult pigeons (Columba livia): } \\
\text { collagen sponges loaded with } 0.5 \\
\mathrm{mg} \text { gentamicin placed in front of } \\
\text { the round window membrane }\end{array}$ & $\begin{array}{l}56 \text { days/BDNF } \\
(625 \mathrm{ng} / \mathrm{mL})\end{array}$ & $\begin{array}{l}\text { BDNF did not enhance the } \\
\text { time course or the extent } \\
\text { of functional recovery and } \\
\text { did not decrease the evoked } \\
\text { ABR threshold }\end{array}$ & BDNF $0.42 \mu \mathrm{g}$ \\
\hline $\begin{array}{l}\text { Agterberg } \\
\text { et al, }{ }^{212} 2008\end{array}$ & $\begin{array}{l}\text { Guinea pigs: kanamycin sulfate, } \\
400 \mathrm{mg} / \mathrm{kg} \text { + furosemide } \\
100 \mathrm{mg} / \mathrm{kg}\end{array}$ & $\begin{array}{l}28 \text { days/BDNF } \\
(100 \mu \mathrm{g} / \mathrm{mL})\end{array}$ & $\begin{array}{l}\text { Increased SGCs shape and } \\
\text { survival rate and density; no } \\
\text { change in ABR }\end{array}$ & BDNF $16.8 \mu \mathrm{g}$ \\
\hline $\begin{array}{l}\text { Song et } \mathrm{al}^{213} \\
2008\end{array}$ & $\begin{array}{l}\text { Rats: gentamicin, } 250 \mathrm{mg} / \mathrm{kg}+ \\
\text { furosemide } 85 \mathrm{mg} / \mathrm{kg}\end{array}$ & $\begin{array}{l}\text { Delayed intervention } \\
\text { ( } 30 \text { days after deafening)/ } \\
28 \text { days/BDNF }(5.4 \mu \mathrm{g} / \mathrm{mL})\end{array}$ & $\begin{array}{l}\text { BDNF enhances SGCs bodies } \\
\text { and peripheral processes } \\
\text { survival }\end{array}$ & BDNF I.35 $\mu \mathrm{g}$ \\
\hline $\begin{array}{l}\text { Agterberg } \\
\text { et al, }{ }^{214} 2009\end{array}$ & $\begin{array}{l}\text { Guinea pigs: kanamycin sulfate, } \\
400 \mathrm{mg} / \mathrm{kg} \text { + furosemide } \\
100 \mathrm{mg} / \mathrm{kg}\end{array}$ & 28 days/BDNF ( $100 \mu g / m L)$ & $\begin{array}{l}\text { Increased SGCs survival } \\
\text { rate; preserved SGCs shape, } \\
\text { response comparable }\end{array}$ & BDNF $16.8 \mu \mathrm{g}$ \\
\hline $\begin{array}{l}\text { Sly et al, }{ }^{215} \\
2012\end{array}$ & $\begin{array}{l}\text { Guinea pigs: kanamycin sulfate, } \\
400 \mathrm{mg} / \mathrm{kg} \text { + furosemide } \\
100 \mathrm{mg} / \mathrm{kg}\end{array}$ & 28 days/BDNF $(62.5 \mu \mathrm{g} / \mathrm{mL})$ & $\begin{array}{l}\text { Improved survival of SGCs, } \\
\text { but not an increase in SGCs } \\
\text { somal area; decreased tone } \\
\text { and click eABR thresholds }\end{array}$ & BDNF $10.5 \mu \mathrm{g}$ \\
\hline $\begin{array}{l}\text { Leake et al, }{ }^{216} \\
2011\end{array}$ & $\begin{array}{l}\text { Young cats: neomycin sulfate, } \\
60 \mathrm{mg} / \mathrm{kg}\end{array}$ & 70 days/BDNF $(94 \mu \mathrm{g} / \mathrm{mL})$ & $\begin{array}{l}\text { Improved survival of the } \\
\text { cochlear SGC neurons; } \\
\text { reduction in thresholds for } \\
\text { electrical ABR }\end{array}$ & BDNF $37.5 \mu \mathrm{g}$ \\
\hline $\begin{array}{l}\text { Waaijer et al, }{ }^{217} \\
2013\end{array}$ & $\begin{array}{l}\text { Guinea pigs: kanamycin sulfate, } \\
400 \mathrm{mg} / \mathrm{kg} \text { + furosemide } \\
100 \mathrm{mg} / \mathrm{kg}\end{array}$ & 28 days/BDNF $(94 \mu \mathrm{g} / \mathrm{mL})$ & $\begin{array}{l}\text { Quantitative and qualitative } \\
\text { improvement of peripheral } \\
\text { processes }\end{array}$ & BDNF $16.8 \mu \mathrm{g}$ \\
\hline $\begin{array}{l}\text { van Loon et al, }{ }^{218} \\
2013\end{array}$ & $\begin{array}{l}\text { Guinea pigs: kanamycin sulfate, } \\
400 \mathrm{mg} / \mathrm{kg} \text { + furosemide } \\
100 \mathrm{mg} / \mathrm{kg}\end{array}$ & 28 days/BDNF ( $100 \mu g / m L)$ & $\begin{array}{l}\text { SGCs significantly bigger in } \\
\text { comparison with normal } \\
\text { throughout the cochlea }\end{array}$ & BDNF $16.8 \mu \mathrm{g}$ \\
\hline \multicolumn{5}{|c|}{ Implanted osmotic minipump (combinations) } \\
\hline $\begin{array}{l}\text { Shinohara } \\
\text { et al, }{ }^{192} 2002\end{array}$ & $\begin{array}{l}\text { Intracochlear infusion of } 24 \mu \mathrm{L} \text { of } \\
10 \% \text { neomycin }\end{array}$ & $\begin{array}{l}26 \text { days/BDNF }(100 \mu g / m L)+ \\
\text { CNTF }(100 \mathrm{ng} / \mathrm{mL})\end{array}$ & $\begin{array}{l}\text { SGCs survival rate is } \\
\text { increased; } A B R \text { threshold is } \\
\text { decreased }\end{array}$ & $\begin{array}{l}\text { BDNF } 31.2 \mu \mathrm{g}+ \\
\text { CNTF }_{\text {AXI }} 31.2 \mu \mathrm{g}\end{array}$ \\
\hline $\begin{array}{l}\text { Yamagata } \\
\text { et al, }{ }^{219} 2004\end{array}$ & $\begin{array}{l}\text { Guinea pigs: intracochlear infusion } \\
\text { of } 10 \% \text { neomycin sulfate } \\
\text { for } 2 \text { days }\end{array}$ & $\begin{array}{l}\text { I } 4 \text { days/BDNF }(100 \mu \mathrm{g} / \mathrm{mL})+ \\
\mathrm{CNTF}_{\text {AXI }}(100 \mathrm{ng} / \mathrm{mL}) . \text { Delay } \\
2 \text { or } 6 \text { weeks }\end{array}$ & $\begin{array}{l}\text { Density of SGCs is increased; } \\
\text { ABR threshold is decreased; } \\
6 \text {-week delay increases in } \\
\text { ABR threshold in comparison } \\
\text { with 2-week delay }\end{array}$ & $\begin{array}{l}\text { BDNF } 8.4 \mu \mathrm{g}+ \\
\text { CNTF }_{\text {AXI }} 8.4 \mu g\end{array}$ \\
\hline $\begin{array}{l}\text { Wise et al, } 220 \\
2005\end{array}$ & $\begin{array}{l}\text { Guinea pigs: kanamycin sulfate, } \\
400 \mathrm{mg} / \mathrm{kg} \text { + furosemide } \\
100 \mathrm{mg} / \mathrm{kg}\end{array}$ & $\begin{array}{l}\text { Delay treatment } 5 \text { or } \\
33 \text { days } / 28 \text { days/BDNF } \\
(50 \mu g / \mathrm{mL})+\text { NTF }(50 \mu g / \mathrm{mL})\end{array}$ & Increased SGCs survival rate & $\begin{array}{l}\text { BDNF } 8.4 \mu \mathrm{g}+ \\
\text { NTF }\end{array}$ \\
\hline
\end{tabular}


Table 2 (Continued)

\begin{tabular}{|c|c|c|c|c|}
\hline Author, year & Animal model & $\begin{array}{l}\text { Method of administration/ } \\
\text { timing/dosing }\end{array}$ & Effect & Total dose \\
\hline $\begin{array}{l}\text { Shepherd } \\
\text { et al, }{ }^{193} 2005\end{array}$ & $\begin{array}{l}\text { Guinea pigs: kanamycin sulfate, } \\
400 \mathrm{mg} / \mathrm{kg}+\text { furosemide } \\
100 \mathrm{mg} / \mathrm{kg}\end{array}$ & 28 days/BDNF $(62.5 \mu \mathrm{g} / \mathrm{mL})$ & $\begin{array}{l}\text { Increased SGCs survival rate; } \\
\text { ES did not provide trophic } \\
\text { support of SGCs }\end{array}$ & BDNF $10 \mu g+E S$ \\
\hline $\begin{array}{l}\text { Miller et al, }{ }^{221} \\
2007\end{array}$ & $\begin{array}{l}\text { Guinea pigs: kanamycin } \\
(420 \mathrm{mg} / \mathrm{kg}) \text { and ethacrynic acid } \\
(60 \mathrm{mg} / \mathrm{kg})\end{array}$ & $\begin{array}{l}\text { Delay treatment: } 4 \text { days, } \\
3 \text { weeks or } 6 \text { weeks } / 26 \text { days/ } \\
\text { BDNF }(100 \mu g / \mathrm{mL})\end{array}$ & $\begin{array}{l}\text { Increased SGCs survival } \\
\text { rate at different treatment } \\
\text { delays, but longer delay led } \\
\text { to decreased overall SGCs } \\
\text { density }\end{array}$ & $\begin{array}{l}\text { BDNF } 31.2 \mu g+ \\
\text { FGF }\end{array}$ \\
\hline $\begin{array}{l}\text { Shepherd } \\
\text { et al, }{ }^{163} 2008\end{array}$ & $\begin{array}{l}\text { Guinea pigs: kanamycin sulfate, } \\
400 \mathrm{mg} / \mathrm{kg}+\text { furosemide } \\
100 \mathrm{mg} / \mathrm{kg}\end{array}$ & $\begin{array}{l}28 \text { days/BDNF }(62.5 \mu \mathrm{g} / \mathrm{mL}) \\
+14 \text { or } 28 \text { days of ES }\end{array}$ & $\begin{array}{l}\text { Chronic ES averted the rapid } \\
\text { loss of SGCs that occurred } \\
\text { after the withdrawal of } \\
\text { exogenous BDNF }\end{array}$ & BDNF $10 \mu g+E S$ \\
\hline $\begin{array}{l}\text { Glueckert } \\
\text { et al, }{ }^{165} 2008\end{array}$ & $\begin{array}{l}\text { Guinea pigs: kanamycin ( } 450 \mathrm{mg} / \\
\mathrm{kg}) \text { followed ( } 2 \text { hours later) with } \\
\text { ethacrynic acid ( } 60 \mathrm{mg} / \mathrm{kg})\end{array}$ & $\begin{array}{l}\text { Immediate and delay } \\
(2 \text { I days }) \text { treatment } / 26 \text { days/ } \\
\text { BDNF }(100 \mu g / m L)+\text { aFGF } \\
(50 \mathrm{ng} / \mathrm{mL})\end{array}$ & $\begin{array}{l}\text { SGCs survival is enhanced, } \\
\text { number of afferent peripheral } \\
\text { processes is increased }\end{array}$ & $\begin{array}{l}\text { BDNF I5.6 } \mu \mathrm{g}+ \\
\text { aFGF }\end{array}$ \\
\hline $\begin{array}{l}\text { Song et al, }{ }^{161} \\
2009\end{array}$ & $\begin{array}{l}\text { Rats: gentamicin, } 250 \mathrm{mg} / \mathrm{kg}+ \\
\text { furosemide } 85 \mathrm{mg} / \mathrm{kg}\end{array}$ & $\begin{array}{l}\text { Delayed intervention } \\
\text { ( } 30 \text { days after deafening)/ } \\
28 \text { days BDNF }(5.4 \mu g / m L)\end{array}$ & $\begin{array}{l}\text { Combination of ES and BDNF } \\
\text { had a synergistic effect: SGCs } \\
\text { soma and peripheral process } \\
\text { survival was increased }\end{array}$ & $\begin{array}{l}\text { BDNF I.35 } \mu \mathrm{g} \\
+ \text { ES }\end{array}$ \\
\hline $\begin{array}{l}\text { Landry et al, }{ }^{162} \\
2011\end{array}$ & $\begin{array}{l}\text { Guinea pigs: kanamycin sulfate, } \\
420 \mathrm{mg} / \mathrm{kg} \text { + furosemide } 130 \mathrm{mg} / \mathrm{kg}\end{array}$ & 28 days/BDNF $(30 \mu g / m L)$ & $\begin{array}{l}\text { Greater SGCs survival and } \\
\text { lower response thresholds for } \\
\text { eABR. ES in combination with } \\
\text { BDNF did not enhance SGCs }\end{array}$ & BDNF $5 \mu \mathrm{g}+\mathrm{ES}$ \\
\hline $\begin{array}{l}\text { Leake et al, }{ }^{160} \\
2013\end{array}$ & $\begin{array}{l}\text { Young cats: neomycin sulfate, } \\
60 \mathrm{mg} / \mathrm{kg}\end{array}$ & 70 days/BDNF (100 $\mu \mathrm{g} / \mathrm{mL})$ & $\begin{array}{l}\text { SGCs numerical density had } \\
\text { been increased }\end{array}$ & $\begin{array}{l}\text { BDNF } 37.5 \mu \mathrm{g} \\
+ \text { ES }\end{array}$ \\
\hline \multicolumn{5}{|c|}{ Viral mediated BDNF delivery systems } \\
\hline $\begin{array}{l}\text { Staecker et al, }{ }^{170} \\
1998\end{array}$ & $\begin{array}{l}\text { CBA } / 6 \mathrm{~J} \text { mice: } 10 \mu \mathrm{L} \text { of neomycin } \\
10^{-1} \mathrm{~mol} / \mathrm{L} \text { solution }\end{array}$ & $\begin{array}{l}\text { Intracochlear injection } \\
\text { through RWM into scala } \\
\text { tympani of } 10 \mu \mathrm{L} \text { HSV } \\
\text { containing BDNF cDNA for } \\
\text { transfection of the SGCs }\end{array}$ & $\begin{array}{l}\text { Up to } 95 \% \text { of the original } \\
\text { population of SGCs survived } \\
\text { at } 28 \text { days }\end{array}$ & HSV.BDNF \\
\hline $\begin{array}{l}\text { Lalwani et al, } \\
2002\end{array}$ & $\begin{array}{l}\text { Guinea pigs: kanamycin } \\
(400 \mathrm{mg} / \mathrm{kg}) \text { and ethacrynic acid } \\
(40 \mathrm{mg} / \mathrm{kg})\end{array}$ & $\begin{array}{l}\text { Implanted osmotic } \\
\text { minipump/ } 8.3 \text { days/AAV- } \\
\text { BDNF/GFP }\left(3 \times 10^{6} \text { viral }\right. \\
\text { particles } / \mathrm{mL})\end{array}$ & $\begin{array}{l}\text { SGCs survival was increased } \\
\text { in basal turn }\end{array}$ & AAV-BDNF/GFP \\
\hline $\begin{array}{l}\text { Nakaizumi } \\
\text { et al, }{ }^{172} 2004\end{array}$ & $\begin{array}{l}\text { Guinea pigs: kanamycin (400 mg/ } \\
\text { kg) and ethacrynic acid (50 mg/kg) }\end{array}$ & $\begin{array}{l}5 \mu \mathrm{L} \text { of an adenoviral } \\
\text { suspension injected into the } \\
\text { scala tympani through the } \\
\text { RWM/ } 28 \text { days }\end{array}$ & $\begin{array}{l}\text { SGCs survival was increased; } \\
\text { no protective action of } \\
\text { CNTF was observed }\end{array}$ & $\begin{array}{l}\text { Ad.BDNF; } \\
\text { Ad.BDNF + } \\
\text { Ad.CNTF }\end{array}$ \\
\hline $\begin{array}{l}\text { Rejali et al, }{ }^{171} \\
2007\end{array}$ & $\begin{array}{l}\text { Guinea pigs: with kanamycin } \\
(420 \mathrm{mg} / \mathrm{kg}) \text { and ethacrynic acid } \\
(52.5 \mathrm{mg} / \mathrm{kg})\end{array}$ & $\begin{array}{l}\mathrm{Cl} \text { electrode coated by } \\
\text { fibroblast cells transduced by } \\
\text { a viral vector with a BDNF } \\
\text { gene insert/48 days }\end{array}$ & $\begin{array}{l}\text { Spiral ganglion survival was } \\
\text { enhanced in basal turn. Cells } \\
\text { infected by Ad.BDNF placed } \\
\text { on the } \mathrm{Cl} \text { in an agarose matrix } \\
\text { could survive for weeks }\end{array}$ & $\begin{array}{l}\text { Ad.BDNF, } \\
\text { fibroblast cells }\end{array}$ \\
\hline $\begin{array}{l}\text { Chikar et al, }{ }^{173} \\
2008\end{array}$ & $\begin{array}{l}\text { Guinea pigs: direct infusion of } \\
60 \mu \mathrm{L} \text { of } 10 \% \text { neomycin into the } \\
\text { perilymph }\end{array}$ & $\begin{array}{l}\text { Single injection }+ \text { intracochlear } \\
\text { implant } / 80 \text { days expression }\end{array}$ & $\begin{array}{l}\text { Increased SGC survival rate; } \\
\text { decrease in eABR threshold }\end{array}$ & $\begin{array}{l}5 \mu \mathrm{L} \text { Ad.BDNF } \\
\left(20 \times 10^{9} \text { adenoviral }\right. \\
\text { particles })\end{array}$ \\
\hline $\begin{array}{l}\text { Wise et al, }{ }^{169} \\
2010\end{array}$ & $\begin{array}{l}\text { Guinea pigs: kanamycin sulfate, } \\
400 \mathrm{mg} / \mathrm{kg} \text { + furosemide } 100 \mathrm{mg} / \mathrm{kg}\end{array}$ & $\begin{array}{l}\text { Single injection of viral } \\
\text { vectors into the scala media }\end{array}$ & $\begin{array}{l}\text { Detection of localized gene } \\
\text { expression; protection SGCs } \\
\text { from degeneration }\end{array}$ & BDNF Ad vectors \\
\hline $\begin{array}{l}\text { Shibata et al, }{ }^{177} \\
2010\end{array}$ & $\begin{array}{l}\text { Guinea pigs: } 10 \mu \mathrm{L} \text { of } 10 \% \\
\text { neomycin sulfate solution into the } \\
\text { scala tympani perilymph }\end{array}$ & $\begin{array}{l}\text { Inoculation with viral } \\
\text { vectors into the scala media } \\
\text { (adenoviral or adeno- } \\
\text { associate viral particle)/ } 4 \text { or } \\
30 \text { days }\end{array}$ & $\begin{array}{l}\text { Increase in the density of } \\
\text { SGCs and inducing of nerve } \\
\text { fibers growth }\end{array}$ & $\begin{array}{l}5 \mu \mathrm{L} \text { of Ad.BDNF, } \\
20 \times 10^{9} \mathrm{Ad} \\
\text { particles; } \\
5 \mu \mathrm{L} \text { of AAV2.GFP. } \\
\text { BDNF, } 8.4 \times 10^{9} \\
\text { AAV2 particles }\end{array}$ \\
\hline
\end{tabular}


Table 2 (Continued)

\begin{tabular}{|c|c|c|c|c|}
\hline Author, year & Animal model & $\begin{array}{l}\text { Method of administration/ } \\
\text { timing/dosing }\end{array}$ & Effect & Total dose \\
\hline $\begin{array}{l}\text { Fukui et al }{ }^{143} \\
2012\end{array}$ & Deaf Pou4f3 mutant mice & $\begin{array}{l}\text { Adenoviral vector with } \\
\text { a mouse BDNF gene } \\
\text { insert, driven by the } \\
\text { cytomegalovirus promoter }\end{array}$ & $\begin{array}{l}\text { Increased number of nerve } \\
\text { fibers in the auditory } \\
\text { epithelium and survival rate } \\
\text { of the auditory neurons in } \\
\text { Rosenthal's canal }\end{array}$ & $\begin{array}{l}\text { I } \mathrm{mL} \text { of } \mathrm{Ad} . \mathrm{BDNF} \\
\left(4 \times 10^{9} \text { adenoviral }\right. \\
\text { particles })\end{array}$ \\
\hline
\end{tabular}

\section{Other delivery systems

$\begin{array}{ll}\text { Li et } \text { al }^{223} & \text { Rats: the induction of bacterial } \\ 2005 & \text { meningitis by Streptococcus } \\ & \text { pneumoniae }\end{array}$ \\ Ito et $\mathrm{al}^{178} \quad$ Guinea pigs: kanamycin \\ $2005 \quad(420 \mathrm{mg} / \mathrm{kg})$ and ethacrynic acid (25 mg/kg)}

\author{
Intracerebroventricular \\ administration $6 \mu \mathrm{g}$ BDNF \\ once a day, 7 days + \\ antibiotic therapy \\ Biodegradable hydrogel \\ immersed in $84 \mu \mathrm{g}$ BDNF \\ was placed on the RWM
}

Decrease in the eABR threshold

BDNF $42 \mu \mathrm{g}$

\begin{tabular}{|c|c|c|c|c|}
\hline $\begin{array}{l}\text { Ito et al }{ }^{178} \\
2005\end{array}$ & $\begin{array}{l}\text { Guinea pigs: kanamycin } \\
(420 \mathrm{mg} / \mathrm{kg}) \text { and ethacrynic acid } \\
(25 \mathrm{mg} / \mathrm{kg})\end{array}$ & $\begin{array}{l}\text { Biodegradable hydrogel } \\
\text { immersed in } 84 \mu \mathrm{g} B \mathrm{BNF} \\
\text { was placed on the RWM }\end{array}$ & $\begin{array}{l}\text { Successful development of } \\
\text { a novel strategy for drug } \\
\text { application to the inner ear; } \\
\text { number of surviving SGCs } \\
\text { was increased; significant } \\
\text { reduce in the eABR threshold } \\
\text { was detected }\end{array}$ & BDNF $84 \mu \mathrm{g}$ \\
\hline $\begin{array}{l}\text { Meen et al }{ }^{148} \\
2009\end{array}$ & $\begin{array}{l}\text { Guinea pigs: } 15 \mathrm{mg} / \mathrm{kg} \\
\text { intraperitoneal cisplatin }\end{array}$ & $\begin{array}{l}\text { Cochleostomy, single } \\
\text { placement of pure BDNF into } \\
\text { the cochlea }\end{array}$ & Prevention of hearing loss & BDNF $0.05 \mu \mathrm{g}$ \\
\hline $\begin{array}{l}\text { Meen et al }{ }^{154} \\
2010\end{array}$ & $\begin{array}{l}\text { Guinea pigs: } 15 \mathrm{mg} / \mathrm{kg} \\
\text { intraperitoneal cisplatin }\end{array}$ & $\begin{array}{l}\text { Cochleostomy, single } \\
\text { placement of pure BDNF into } \\
\text { the cochlea }\end{array}$ & $\begin{array}{l}\text { No changes in eABR click } \\
\text { thresholds }\end{array}$ & BDNF $0.05 \mu \mathrm{g}$ \\
\hline $\begin{array}{l}\text { Havenith et al }{ }^{179} \\
201 \mathrm{I}\end{array}$ & $\begin{array}{l}\text { Guinea pigs: kanamycin sulfate, } \\
400 \mathrm{mg} / \mathrm{kg} \text { + furosemide } \\
100 \mathrm{mg} / \mathrm{kg}\end{array}$ & $\begin{array}{l}\text { Gelfoam }^{\circledast} \text { (Pharmacia and } \\
\text { Upjohn) containing BDNF, } \\
\text { placed on the round window } \\
\text { membrane/ } 28 \text { days }\end{array}$ & $\begin{array}{l}\text { Increased SGC survival rate } \\
\text { in basal turn, but no effect on } \\
\text { SGC shape and size; no effect } \\
\text { on eABR thresholds }\end{array}$ & BDNF $6 \mu \mathrm{g}$ \\
\hline $\begin{array}{l}\text { Pettingill et al }{ }^{182} \\
201 \mathrm{I}\end{array}$ & $\begin{array}{l}\text { Guinea pigs: kanamycin sulfate, } \\
520 \mathrm{mg} / \mathrm{kg} \text { + furosemide } \\
130 \mathrm{mg} / \mathrm{kg}\end{array}$ & $\begin{array}{l}\text { Shwann cell-based gene } \\
\text { transfer combined with } \\
\text { alginate encapsulation } \\
\text { technology/28 days }\end{array}$ & $\begin{array}{l}\text { Greater auditory SGCs } \\
\text { survival }\end{array}$ & $\begin{array}{l}\text { BDNF-Schwann } \\
\text { cells encapsulated } \\
\text { in a biocompatible } \\
\text { matrix }\end{array}$ \\
\hline
\end{tabular}

Abbreviations: BDNF, brain-derived neurotrophic factor; SGCs, spiral ganglion cells; HCs, hair cells; ABRs, auditory brainstem responses; CNTF, ciliary neurotrophic factor; NTF, neurotrophic factor; ES, electrical stimulation; FGF, fibroblast growth factor I; aFGF, acidic fibroblast growth factor; eABR, electronic ABR; HSV, herpes simplex virus; RWM, round window membrane; AAV, adeno-associated virus; GFP, green fluorescent protein; Cl, cochlear implant; Ad.BDNF, adenovirus vector containing BDNF.

minor surgery may provide long-lasting delivery of more than 2 weeks. ${ }^{150}$ Technically, direct delivery of pure BDNF protein is carried out by exploiting implanted osmotic minipump with drug primed cannulas that release of 0.5 or $0.25 \mu \mathrm{L} / \mathrm{h}$ of human recombinant BDNF. The overall dose of BDNF appeared to be important when using experimental animals with different sizes. The total effective dose range for guinea pigs was 10-16.8 $\mu \mathrm{g} /$ ear, for rats was $1.35 \mu \mathrm{g}$, and for cats was $37.5 \mu \mathrm{g}$ (Table 2). Of interest, Radeloff and Smolders ${ }^{151}$ investigated the effectiveness of the treatment in deaf pigeons using a very small dose of $0.42 \mu \mathrm{g}$ BDNF/ear. They revealed no reduction in the auditory brain stem responses (ABR) threshold, thus concluding that $\mathrm{BDNF}$ was not a limiting factor during $\mathrm{HC}$ regeneration and reinnervation. Nonetheless, the analysis of the corresponding doses, used for other animals showed that the application of such small amount of drug was the main reason for the unsuccessful result rather than other factors. Shoji et al ${ }^{149}$ also showed that 0.144 and $1.44 \mu \mathrm{g}$ BDNF were not efficacious in the protection of the sensory epithelium in guinea pigs with acoustic trauma. The authors admitted that they had used five times less dose than other researchers. However, they had compared BDNF with NT-3 action and had assumed that BDNF did not have any specific action of sensory epithelium. Meanwhile, another study claimed that BDNF had no protective effect on HCs at 15 days (total $9 \mu \mathrm{g}$ of BDNF) and 60 days $(36 \mu \mathrm{g})$, but some effects at 30 days $(18 \mu \mathrm{g}) .{ }^{152}$ One more study demonstrated that direct placement of $0.05 \mu \mathrm{g}$ of BDNF into the inner ear after cochleostomy did not improve or treat hearing loss after cisplastin-induced deafening. ${ }^{148}$ At the same time, the positive effect of $8.4 \mathrm{ng}$ BDNF on SGCs survival in deaf guinea pigs has remained controversial in the context of dose-dependent manner of BDNF action. ${ }^{153}$ As an alternative approach cochleostomy was performed. The posterior part of the tympanic membrane was separated, then 
the underlying cochlea was opened into the scala tympani just anterior to the round window using a small diameter cutting drill and, finally, pure BDNF was placed there. ${ }^{148}$ Due to lack of therapeutic effectiveness, ${ }^{154}$ this method needs further investigation to establish an effective scheme of BDNF administration.

\section{Combinations with BDNF}

One of the main limitations of using osmotic minipumps is the transient protection of SGCs. ${ }^{152}$ Indeed, the survival effects of BDNF on neuronal cells were not observed after the treatment phase. ${ }^{155}$ This phenomenon has been widely confirmed by other studies in different neural systems, indicating that the survival effects of BDNF, as well as other growth factors only last so long as the treatment itself. ${ }^{156}$ To overcome this limitation or to increase the effectiveness, the usage of several combinations of the BDNF with other growth factors or electrical stimulation (ES) was suggested (Table 2). Some studies have established that a chronic depolarization of the auditory nerve via ES provided a trophic effect on SGCs without the contact of HCs, ${ }^{157,158}$ however, these findings turned out to be controversial. ${ }^{159}$ The effectiveness of the combination of BDNF with ES on SGCs survival also appeared to be not so universal (Table 2). This inconsistency displayed substantial methodological differences among these studies. The selection of animals can also be crucial for such studies: cats ${ }^{160}$ and rats $^{161}$ are possibly more sensitive to ES than guinea pigs. ${ }^{162}$ For future translation to patients, it is critical to note that continued chronic ES after cessation of BDNF delivery had significantly reduced the rate of SGCs loss. ${ }^{163}$ In addition, there was also evidence about the protective effects on the SGCs that employed other neurotrophic factors, such as glial cell line-derived neurotrophic factor (GDNF), ${ }^{164}$ fibroblast growth factor (FGF), ${ }^{165}$ and ciliary neurotrophic factor (CNTF). ${ }^{166}$ The combination of BDNF and any one of the other growth factors has been reported to be more effective than either agent alone in protecting SGCs and in decreasing ABR threshold (Table 2). Thus, the combination of BDNF with other agents may be promising as a potential therapeutic agent to promote the survival of SGCs in the auditory system. However, mini-osmotic pump appears to be inappropriate for use in patients due to fixed delivery period and high risk of bacterial contamination related to the surgical technique of inserting the pump into the cochlea and cannula clogging. ${ }^{167}$

\section{Viral mediated BDNF delivery}

Viral vectors are known to be a potent method for gene delivery, which can be successfully applied for the treatment of the inner ear. Several types of viruses have been created for inner ear transfection: Ad, AAV, lentivirus, herpes simplex virus (HSV), vaccinia virus, and Sendai virus. ${ }^{168}$ It was considered that gene delivery via cochleostomy into the basal turn of the scala media was more effective than via RWM due to the existence of tight junctions between the scala tympani and scala media. ${ }^{169} \mathrm{HSV}$, as a gene transfer vector is identified to be a promising carrier because of its ability to infect several cell types, including quiescent and proliferating cells. HSV with BDNF had successfully infected HCs and neurons, and this saved $94.7 \%$ of the original population of SGCs after aminoglycoside ototoxic injuries. ${ }^{170}$ Additionally, Ad vectors can also be beneficial, basically, due to their possibility to infect different cell types effectively and to provide relatively fast beginning of gene production following infection. The first successful transfection by Ad of retinal Muller cells in vivo, which then were able to secrete BDNF, was made by Di Polo et al. ${ }^{121}$ Later, the same methodology was used for gene delivery into the inner ear. Rejali et al ${ }^{171}$ demonstrated that Ad.BDNF transfected guinea pig fibroblast cells could release BDNF in vitro. The administration of Ad.BDNF into the cochlea following aminoglycoside deafening had been reported to enhance SGC survival rate at 21 days, ${ }^{169}$ 28 days, ${ }^{172}$ and 48 days ${ }^{171}$ postinoculation, and to decrease psychophysical as well as ABR thresholds. ${ }^{173}$ Recently, it was also found that Ad.BDNF had improved the auditory nerve survival and peripheral sprouting in Pou $4 f 3$ mutant mouse ears. ${ }^{143}$ However, adenovirus gene expression appears to be transitory, hence high levels of transgenes cannot be persistent over a long period. Moreover, another limitation of $\mathrm{Ad}$ vectors is the activation of immune responses. ${ }^{174}$ One more effective viral vector, AAV, had shown different cell tropisms at different serotypes. ${ }^{175}$ Among them, AAV2 may easily transduce HCs and SGCs in vitro, ${ }^{175}$ although, in vivo, it was revealed that this vector can only infect spiral limbus, spiral ligament, and spiral ganglion cells, following its delivery across the RWM. ${ }^{176}$ Besides, a recent paper had demonstrated a successful transfection of the basilar membrane area (epithelial and mesothelial cells) by AAV2 carrying the $B D N F$ gene. ${ }^{177}$ Moreover, AAV is considered to be one of the most promising gene therapy vectors for human clinical trials. ${ }^{168}$ However, there are some limitations for AAV vectors, which include their inability to perform effective gene transduction in patients with antibodies against AAV or those with AAV infection in the past, for instance, in childhood when it could be very common. Additionally, the risk of virus toxicity due to the application of viral vectors continues to be a major restriction for its clinical use. 


\section{Biodegradable materials for sustained BDNF release}

In order to achieve sustained delivery of BDNF, other approaches were tested in vivo. A promising advance is the development of extracochlear application systems based on the ability of BDNF to diffuse across the RMW. Biodegradable hydrogel infiltrated with BDNF ${ }^{178}$ has been successfully applied as a sustained-release carrier. With that, Ito et al ${ }^{178}$ demonstrated significantly higher BDNF concentration in the guinea pigs' cochlear perilymph in the hydrogel group in comparison to either control animals or the group that received an injection through the RWM. These data provided factual evidence for the diffusion of BDNF across the guinea pig's round window. As a result, after 1 week, animals implanted with BDNF-containing collagen hydrogels had lower ABR thresholds and higher density of surviving SGCs from the basal up to the apical cochlear turns, moreover, the perilymph level of BDNF was over 100 times higher than control animals treated with saline. ${ }^{178}$ Another option for sustained BDNF release to the cochlea was a gelatin sponge (Gelfoam ${ }^{\circledR}$, Pharmacia and Upjohn, Bridgewater, NJ, USA) placed onto RMW. ${ }^{179}$ Of interest, Havenith et al ${ }^{179}$ had used a 10-fold less dose of BDNF than Ito et al. ${ }^{178}$ Anyway, both studies are very significant, as they showed the possibility of usage of biodegradable carriers that contributed to low risk of cell toxicity. Nowadays, for the treatment of hearing loss, among all growth factors, only recombinant human insulin-like growth factor-1 (IGF-1) combined with gelatin hydrogel has been approved for clinical trials. It has finished Phase I/IIa clinical trial on the safety and efficacy of local IGF-1 application via the RWM using gelatin hydrogel for patients with acute sensorineural hearing loss. ${ }^{180}$

\section{Cell-based BDNF delivery}

Apart from other approaches, Schwann cells or fibroblasts have been suggested as cell therapy methods. These types of cells have been tested both in vitro and in vivo. ${ }^{181}$ The disadvantages include difficulties with the retrieval of cells and the potential to spread viral particles intracranially. ${ }^{181}$ One study had suggested the creation of an electrode, which can secrete BDNF, using the ex vivo gene transfer pattern employing Ad containing $B D N F$ gene insert. The proposed electrode was coated with fibroblasts transduced with the BDNF transgene. Then, the electrode with encased BDNF was transplanted into the scala tympani in a hydrogel scaffold on a CI to increase the survival of SGCs. ${ }^{171}$ Another study that combined cell-based gene transfer with alginate technology, had demonstrated the survival effects on auditory neurons of encapsulated BDNF-expressing Schwann cells. ${ }^{182}$ Such transplanted cells, encapsulated in a biocompatible matrix, would be protected against strong immune responses, and this would allow the patients to avoid using toxic immunodepressants, thus minimizing the associated risk of transplant rejection.

Without a doubt, osmotic minipump, gene therapy, stem cell therapy, and cochleostomy are hopeful steps toward successful treatment of the degeneration of SGCs in the inner ear and the loss of hearing. However, it is difficult to predict how these technologies can be translated into clinical practice. Moreover, BDNF is documented to act in dosedependent manner, while accurate control of the dose, for some approaches, has remained to be a challenge.

\section{Nanoparticulate delivery}

NP delivery to the inner ear is a new promising strategy for targeting compounds to the cochlea in a sustained and controlled manner. Poly(D,L-lactide-co-glycolide acid) PLGA, a biodegradable and nontoxic polymer approved by US Food and Drug Administration for human use, has been established as the best nanoparticulate drug carrier. ${ }^{183}$ Furthermore, recent work had demonstrated that systemic application of PLGA nanoparticles loaded with rhodamine resulted in the appearance of NPs in the liver, cochlea, and kidney, however, the placement of NPs into the RMW caused substantially higher accumulation of rhodamine in the scala tympani. ${ }^{184}$ Another study had shown a wide distribution of PLGA throughout all turns of chinchilla cochlea when NPs were placed upon the RWM for a duration of 40 minutes. ${ }^{185}$ Although delivery of BDNF to the inner ear using NPs has not been studied yet, either for systemic or for intratympanic administration, we assume that PLGA nanoparticles are a very promising approach for the inner ear drug targeting.

\section{Similarities, controversies, and future prospects}

Hearing or vision loss is not only a prominent burden to the health care system, but also a ground for the worse quality of life associated with isolation and decreased socializing and, as a consequence, leads to an uprising of symptoms of depression on individuals. ${ }^{186,187}$ In both cases, the neurodegenerative disorder of neurons of sensory organs is a crucial causal factor. Together with this, BDNF is considered to be a promising and an effective protein that is able to protect and increase the survival of RGCs as well as SGCs.

Besides, systemic delivery with oral, intravenous, and intramuscular routes are still thought as the most appropriate methods of drug administration, and they are currently recognized as the first line tactic in the treatment of the 
inner ear or eye posterior segment disorders in clinic. On the other hand, the availability of drug in the posterior eye segment or scala tympani following systemic administration is limited by the presence of $\mathrm{BRB}$ or $\mathrm{BCB}$, which are almost nonpermeable to large proteins, like BDNF (14 kDa). A variety of efforts related to the delivery of pure BDNF to the target organs has been documented in many research papers. For retinal diseases, single or multiple intravitreal injections are known as the most convenient methods, while for the inner ear, implantation of the osmotic minipump is the most applicable. It turned out that establishing the dose could be a challenging task which, fairly frequently, was not so universal. As mentioned earlier, $5 \mu \mathrm{g}$ of BDNF for one rat's eye was as an optimal dose, whereas $30 \mu \mathrm{g}$ BDNF was chosen as the optimal dose for cats. As for the ear, studies have shown that the total effective dose range for guinea pigs was $10-16.8 \mu \mathrm{g} / \mathrm{ear}$, for rats was $1.35 \mu \mathrm{g}$, and for cats was $37.5 \mu \mathrm{g}$. Even if the doses look comparable, it would be incorrect to compare them for some obvious reasons, for instance, intravitreal injection is mostly single dosing, whereas osmotic minipump delivers the drug over a span of 2 weeks. Also, of note is the fact that the volume of human eye is $\sim 4 \mathrm{~mL}$, while the volume of cochlea is lesser, 70-80 $\mu \mathrm{L} .{ }^{188}$ Overall, it has been explicitly clear that for both eye and ear, the BDNF has a dose-dependent manner of action. Eventually, it has been shown, that increasing the dose may lead to lack of effectiveness of BDNF neuroprotection, ${ }^{97}$ which is possibly due to negative feedback-mediated downregulation of TrkB receptors. ${ }^{189}$ Additionally, overdosing of BDNF enhances the excitability of the neurons that contribute to the initiation of seizures, ${ }^{190}$ thus, it may be epileptogenic. ${ }^{191}$ Furthermore, BDNF is found to cause an increase in the formation of free radicals, specifically nitric oxide (NO), hence boosting necrotic cell death. ${ }^{116}$ To improve its effectiveness, reduce adverse effects, or to overcome the limitations, like transient action, it has been suggested that BDNF should be used in combinations. Mixtures of BDNF with other growth factors led to the enhancement of neuronal survival. Of interest, CNTF was exploited for both retina and inner ear, and it showed positive effect for immediate and delayed after-deafness treatment, ${ }^{192}$ while for retina treatment, no additive effect was observed. ${ }^{114}$ Another study had proposed the usage of LINGO-1 antagonist in combination with BDNF in rats with progressive neuropathy secondary to high intraocular pressure. LINGO-1 antagonist prevented the negative regulation of activity for TrkB receptors during interaction with BDNF and showed long-term protection for RGCs. ${ }^{112}$ Besides, the combination with free radical scavenger $\mathrm{S}-\mathrm{PBN}{ }^{101,116}$ or NO synthase inhibitor 1-NAME substantially reduced level of $\mathrm{NO}$ and improved RGCs survival in comparison to BDNF alone. ${ }^{93,116}$ As for deafened guinea pigs, ES was used in combination with BDNF to prolong survival of SGCs. ${ }^{163,193}$ Further, medicinal forms with sustained release appear to be another approach directed to overcome the transient effect of BDNF. Biodegradable polymer drug-delivery systems, like biodegradable hydrogel or Gelfoam ${ }^{\circledR}$ with BDNF, have been successfully applied for sustained delivery into the inner ear. ${ }^{179}$ For the treatment of retinal disease, there is no documentation about BDNF delivery into the eye using biodegradable polymers. However, one such application had been tested in models of glaucoma, but by exploiting NGF. This showed that biodegradable PLGA microspheres, mixed with bioactive molecules with subsequent degradation of the material in vivo, had resulted in slow, sustained NGF release. ${ }^{134}$ Alternatively, local drug delivery method, which employs viral gene, has been widely used for both eye and inner ear treatments. Furthermore, first, Ad vector was established by Dr Adriana Di Polo for BDNF therapy of axotomized rats. ${ }^{121}$ Of interest, this adenoviral vector was later given by Dr Di Polo as a gift to the researchers who investigated the possibility of using gene therapy in deaf guinea pigs. ${ }^{171,172}$ Among the different viral vectors, AAV is the most promising to be translated to patients due to its safety, ${ }^{194}$ different cell tropisms, and sustained expression of BDNF. ${ }^{118}$ Recent advances in cell-based therapy have met the needs in long-term stable delivery of BDNF. Schwann cells, which are capable of expressing BDNF, have been effectively transplanted into the subretinal space of RCS rat strains $^{105}$ and to the guinea pig's cochlea. ${ }^{182}$ However, viral vector and cell-based therapy are still limited by surgical technique and human immune system. As a promising solution to protect cells from rejection and tumorigenicity, cell transplantation and gene transfer, combined with encapsulation technologies, has been suggested. ${ }^{182}$ BDNF-expressing Schwann cells with alginate encapsulation technology have been applied to deaf guinea pigs and this showed survival effect on auditory neurons. Although BDNF has not been used with such strategy for the treatment of posterior eye segment, data about a Phase I clinical trial exploiting immortalized human retinal pigmented epithelial cells overexpressing CNTF for the treatment of retinitis pigmentosa have been published. ${ }^{195}$

A major challenge that has been raised is how to translate to patients the delivery of BDNF into these organs. Some drawbacks may be associated with the technique of administration itself. For instance, it was demonstrated that surgical manipulation on the patient's ear like cochlear implantation has led to a significant risk of deafness. ${ }^{196}$ At the same time, 
although repeated intravitreal injections of growth factors has become usual in many retinal clinics, other less invasive routes of administration capable of stable long-term delivery are of interest. ${ }^{134}$ In future, the delivery of BDNF to the inner ear or to the posterior segment of the eye via nanotechnologybased products should be investigated more extensively. To date, some successes in the delivery of various therapeutics into the CNS have been widely recognized. Many studies on the different approaches to overcome the BBB are based on the knowledge of transport mechanisms of diverse biological molecules across the BBB. In fact, lots of techniques have been established to facilitate the penetration of NPs into the brain, namely carrier-mediated transport, receptor-mediated transcytosis, adsorptive-mediated transcytosis and cellmediated transcytosis. ${ }^{15}$ A comprehensive understanding of BRB and BCB physiology and matching them with the accumulated knowledge on BBB function should play a key role in the search for new strategies and will elucidate the potential of using NPs for the treatment of degenerative disorders of the retina and inner ear. It is possible to expect that targeted BDNF delivery that employs NPs should assist to bypass the limitations related to surgical intrusion into the sensory organ and simultaneously provide therapeutically effective concentration of molecule at the site of action and avoid unwanted systemic effects.

\section{Conclusion}

Currently, various therapeutic strategies to treat inner ear and posterior eye segment diseases are limited by poor systemic delivery of BDNF. Although local delivery into the eye or inner ear provides a high concentration of BDNF with reduced systemic adverse reactions, anatomic features of these sensory organs require surgical intervention to achieve this delivery, which may lead to severe complications when translated to patients. It would be excellent to apply knowledge about BBB permeation to create a clinically feasible technique for BDNF delivery into the inner ear or posterior eye segment exploiting systemic administration. We assume that promising BDNFcontaining drug for the treatment of inner ear and retina disorders should be designed as safe and effective medicine based on nanoparticulate drug delivery systems. This can make possible the long-lasting rescue of auditory and optic neurons from degenerative effects, substantially improving the quality of life of deaf or blind people.

\section{Acknowledgment}

The authors would like to thank the National Defence University of Malaysia for fully supporting this work.

\section{Disclosure}

The authors report no conflicts of interest in this work.

\section{References}

1. Allen SJ, Watson JJ, Shoemark DK, Barua NU, Patel NK. GDNF, NGF and BDNF as therapeutic options for neurodegeneration. Pharmacol Ther. 2013;138(2):155-175.

2. Nagahara AH, Merrill DA, Coppola G, et al. Neuroprotective effects of brain-derived neurotrophic factor in rodent and primate models of Alzheimer's disease. Nat Med. 2009;15(3):331-337.

3. Levivier M, Przedborski S, Bencsics C, Kang UJ. Intrastriatal implantation of fibroblasts genetically engineered to produce brain-derived neurotrophic factor prevents degeneration of dopaminergic neurons in a rat model of Parkinson's disease. J Neurosci. 1995;15(12):7810-7820.

4. Bemelmans AP, Horellou P, Pradier L, Brunet I, Colin P, Mallet J. Brainderived neurotrophic factor-mediated protection of striatal neurons in an excitotoxic rat model of Huntington's disease, as demonstrated by adenoviral gene transfer. Hum Gene Ther. 1999;10(18):2987-2997.

5. Li W, Pozzo-Miller L. BDNF deregulation in Rett syndrome. Neuropharmacology. 2014;76(Pt C):737-746.

6. Schabitz WR, Schwab S, Spranger M, Hacke W. Intraventricular brainderived neurotrophic factor reduces infarct size after focal cerebral ischemia in rats. J Cereb Blood Flow Metab. 1997;17(5):500-506.

7. Blaha GR, Raghupathi R, Saatman KE, McIntosh TK. Brain-derived neurotrophic factor administration after traumatic brain injury in the rat does not protect against behavioral or histological deficits. Neuroscience. 2000;99(3):483-493.

8. Hoshaw BA, Malberg JE, Lucki I. Central administration of IGF-I and BDNF leads to long-lasting antidepressant-like effects. Brain Res. 2005;1037(1-2):204-208.

9. Otis JM, Fitzgerald MK, Mueller D. Infralimbic BDNF/TrkB enhancement of GluN2B currents facilitates extinction of a cocaine-conditioned place preference. J Neurosci. 2014;34(17):6057-6064.

10. Koeva YA, Sivkov ST, Akabaliev VH, et al. Brain-derived neurotrophic factor and its serum levels in schizophrenic patients. Folia Med. 2014; 56(1):20-23.

11. Kalra S, Genge A, Arnold DL. A prospective, randomized, placebocontrolled evaluation of corticoneuronal response to intrathecal BDNF therapy in ALS using magnetic resonance spectroscopy: feasibility and results. Amyotroph Lateral Scler Other Motor Neuron Disord. 2003;4(1):22-26.

12. Makar TK, Bever CT, Singh IS, et al. Brain-derived neurotrophic factor gene delivery in an animal model of multiple sclerosis using bone marrow stem cells as a vehicle. J Neuroimmunol. 2009;210(1-2): $40-51$.

13. Chen Y, Liu L. Modern methods for delivery of drugs across the bloodbrain barrier. Adv Drug Deliv Rev. 2012;64(7):640-665.

14. Pardridge WM. Drug transport across the blood-brain barrier. J Cereb Blood Flow Metab. 2012;32(11):1959-1972.

15. Alyautdin R, Khalin I, Nafeeza MI, Haron MH, Kuznetsov D. Nanoscale drug delivery systems and the blood-brain barrier. Int J Nanomedicine. 2014;9:795-811.

16. Mannermaa E, Vellonen KS, Urtti A. Drug transport in corneal epithelium and blood-retina barrier: emerging role of transporters in ocular pharmacokinetics. Adv Drug Deliv Rev. 2006;58(11):1136-1163.

17. Juhn SK, Rybak LP, Fowlks WL. Transport characteristics of the blood-perilymph barrier. Am J Otolaryngol. 1982;3(6):392-396.

18. Levi-Montalcini R. The nerve growth factor 35 years later. Science. 1987;237(4819):1154-1162.

19. Barde YA, Edgar D, Thoenen H. Purification of a new neurotrophic factor from mammalian brain. EMBO J. 1982;1(5):549-553.

20. Leibrock J, Lottspeich F, Hohn A, et al. Molecular cloning and expression of brain-derived neurotrophic factor. Nature. 1989;341(6238): 149-152.

21. Pattarawarapan M, Burgess K. Molecular basis of neurotrophin-receptor interactions. J Med Chem. 2003;46(25):5277-5291. 
22. Robinson RC, Radziejewski C, Spraggon G, et al. The structures of the neurotrophin 4 homodimer and the brain-derived neurotrophic factor/ neurotrophin 4 heterodimer reveal a common Trk-binding site. Protein Sci. 1999;8(12):2589-2597.

23. Robinson RC, Radziejewski C, Stuart DI, Jones EY. Structure of the brain-derived neurotrophic factor/neurotrophin 3 heterodimer. Biochemistry. 1995;34(13):4139-4146.

24. Maisonpierre PC, Le Beau MM, Espinosa R 3rd, et al. Human and rat brainderived neurotrophic factor and neurotrophin-3: gene structures, distributions, and chromosomal localizations. Genomics. 1991;10(3):558-568.

25. Hanson IM, Seawright A, van Heyningen V. The human BDNF gene maps between FSHB and HVBS1 at the boundary of 11p13-p14 Genomics. 1992;13(4):1331-1333.

26. Lommatzsch M, Braun A, Mannsfeldt A, et al. Abundant production of brain-derived neurotrophic factor by adult visceral epithelia. Implications for paracrine and target-derived Neurotrophic functions. Am J Pathol. 1999;155(4):1183-1193.

27. Garces MF, Sanchez E, Torres-Sierra AL, et al. Brain-derived neurotrophic factor is expressed in rat and human placenta and its serum levels are similarly regulated throughout pregnancy in both species. Clin Endocrinol. 2014;81(1):141-151.

28. Lessmann V, Gottmann K, Malcangio M. Neurotrophin secretion: current facts and future prospects. Prog Neurobiol. 2003;69(5):341-374

29. Negro A, Tavella A, Grandi C, Skaper SD. Production and characterization of recombinant rat brain-derived neurotrophic factor and neurotrophin-3 from insect cells. J Neurochem. 1994;62(2):471-478.

30. Seidah NG, Benjannet S, Pareek S, Chretien M, Murphy RA. Cellular processing of the neurotrophin precursors of NT3 and BDNF by the mammalian proprotein convertases. FEBS Lett. 1996;379(3):247-250.

31. Gray K, Ellis V. Activation of pro-BDNF by the pericellular serine protease plasmin. FEBS Lett. 2008;582(6):907-910.

32. Teng HK, Teng KK, Lee R, et al. ProBDNF induces neuronal apoptosis via activation of a receptor complex of p75NTR and sortilin. J Neurosci. 2005;25(22):5455-5463.

33. Yang M, Lim Y, Li X, Zhong JH, Zhou XF. Precursor of brain-derived neurotrophic factor (proBDNF) forms a complex with Huntingtin-associated protein-1 (HAP1) and sortilin that modulates proBDNF trafficking, degradation, and processing. J Biol Chem. 2011;286(18):16272-16284.

34. Egan MF, Kojima M, Callicott JH, et al. The BDNF val66met polymorphism affects activity-dependent secretion of BDNF and human memory and hippocampal function. Cell. 2003;112(2):257-269.

35. Ultsch MH, Wiesmann C, Simmons LC, et al. Crystal structures of the neurotrophin-binding domain of TrkA, TrkB and TrkC. J Mol Biol. 1999;290(1):149-159.

36. Naylor RL, Robertson AG, Allen SJ, et al. A discrete domain of the human TrkB receptor defines the binding sites for BDNF and NT-4. Biochem Biophys Res Commun. 2002;291(3):501-507.

37. Massa SM, Yang T, Xie Y, et al. Small molecule BDNF mimetics activate TrkB signaling and prevent neuronal degeneration in rodents J Clin Invest. 2010;120(5):1774-1785.

38. Middlemas DS, Lindberg RA, Hunter T. TrkB, a neural receptor proteintyrosine kinase: evidence for a full-length and two truncated receptors. Mol Cell Biol. 1991;11(1):143-153.

39. Barbacid M. The Trk family of neurotrophin receptors. J Neurobiol. 1994;25(11):1386-1403.

40. Wong J, Rothmond DA, Webster MJ, Weickert CS. Increases in two truncated TrkB isoforms in the prefrontal cortex of people with schizophrenia. Schizophr Bull. 2013;39(1):130-140.

41. Arevalo JC, Wu SH. Neurotrophin signaling: many exciting surprises! Cell Mol Life Sci. 2006;63(13):1523-1537.

42. Biffo S, Offenhauser N, Carter BD, Barde Y-A. Selective binding and internalisation by truncated receptors restrict the availability of BDNF during development. Development. 1995;121(8):2461-2470.

43. Eide FF, Vining ER, Eide BL, Zang K, Wang XY, Reichardt LF Naturally occurring truncated trkB receptors have dominant inhibitory effects on brain-derived neurotrophic factor signaling. J Neurosci. 1996;16(10):3123-3129.
44. Gruss HJ, Dower SK. The TNF ligand superfamily and its relevance for human diseases. Cytokines Mol Ther. 1995;1(2):75-105.

45. Frade JM, Barde YA. Nerve growth factor: two receptors, multiple functions. Bioessays. 1998;20(2):137-145.

46. Tomellini E, Lagadec C, Polakowska R, Le Bourhis X. Role of p75 neurotrophin receptor in stem cell biology: more than just a marker. Cell Mol Life Sci. 2014;71(13):2467-2481.

47. Barker PA. p75NTR is positively promiscuous: novel partners and new insights. Neuron. 2004;42(4):529-533.

48. Skeldal S, Matusica D, Nykjaer A, Coulson EJ. Proteolytic processing of the p 75 neurotrophin receptor: a prerequisite for signalling?: Neuronal life, growth and death signalling are crucially regulated by intra-membrane proteolysis and trafficking of p75(NTR). Bioessays. 2011;33(8): 614-625.

49. Hempstead BL, Martin-Zanca D, Kaplan DR, Parada LF, Chao MV. High-affinity NGF binding requires coexpression of the trk protooncogene and the low-affinity NGF receptor. Nature. 1991;350(6320): $678-683$.

50. Nykjaer A, Lee R, Teng KK, et al. Sortilin is essential for proNGFinduced neuronal cell death. Nature. 2004;427(6977):843-848.

51. Jacobsen L, Madsen P, Jacobsen C, Nielsen MS, Gliemann J, Petersen CM. Activation and functional characterization of the mosaic receptor SorLA/LR11. J Biol Chem. 2001;276(25):22788-22796.

52. Atwal JK, Massie B, Miller FD, Kaplan DR. The TrkB-Shc site signals neuronal survival and local axon growth via MEK and P13-kinase. Neuron. 2000;27(2):265-277.

53. Cowansage KK, LeDoux JE, Monfils M-H. Brain-derived neurotrophic factor: a dynamic gatekeeper of neural plasticity. Curr Mol Pharmacol. 2010;3(1):12-29.

54. Chao MV. Neurotrophins and their receptors: a convergence point for many signalling pathways. Nature Reviews Neuroscience. 2003; 4(4):299-309.

55. Reichardt LF. Neurotrophin-regulated signalling pathways. Philos Trans $R$ Soc Lond B Biol Sci. 2006;361(1473):1545-1564.

56. Amaral MD, Pozzo-Miller L. TRPC3 channels are necessary for brainderived neurotrophic factor to activate a nonselective cationic current and to induce dendritic spine formation. J Neurosci. 2007;27(19): 5179-5189.

57. Blanquet PR, Mariani J, Derer P. A calcium/calmodulin kinase pathway connects brain-derived neurotrophic factor to the cyclic AMPresponsive transcription factor in the rat hippocampus. Neuroscience. 2003;118(2):477-490.

58. Tardito D, Perez J, Tiraboschi E, Musazzi L, Racagni G, Popoli M. Signaling pathways regulating gene expression, neuroplasticity, and neurotrophic mechanisms in the action of antidepressants: a critical overview. Pharmacol Rev. 2006;58(1):115-134.

59. Zheng WH, Quirion R. Comparative signaling pathways of insulin-like growth factor-1 and brain-derived neurotrophic factor in hippocampal neurons and the role of the PI3 kinase pathway in cell survival. $J \mathrm{Neu}$ rochem. 2004;89(4):844-852.

60. Perez-Navarro E, Gavalda N, Gratacos E, Alberch J. Brain-derived neurotrophic factor prevents changes in Bcl-2 family members and caspase- 3 activation induced by excitotoxicity in the striatum. $J \mathrm{Neu}$ rochem. 2005;92(3):678-691.

61. Takei N, Inamura N, Kawamura M, et al. Brain-derived neurotrophic factor induces mammalian target of rapamycin-dependent local activation of translation machinery and protein synthesis in neuronal dendrites. J Neurosci. 2004;24(44):9760-9769.

62. Slipczuk L, Bekinschtein P, Katche C, Cammarota M, Izquierdo I, Medina JH. BDNF activates mTOR to regulate GluR1 expression required for memory formation. PloS One. 2009;4(6):e6007.

63. Numakawa T, Suzuki S, Kumamaru E, Adachi N, Richards M, Kunugi H. BDNF function and intracellular signaling in neurons. Histol Histopathol. 2010;25(2):237-258.

64. Hao Y, Creson T, Zhang L, et al. Mood stabilizer valproate promotes ERK pathway-dependent cortical neuronal growth and neurogenesis. J Neurosci. 2004;24(29):6590-6599. 
65. Bibel M, Hoppe E, Barde YA. Biochemical and functional interactions between the neurotrophin receptors trk and p75NTR. EMBO J. 1999; 18(3):616-622.

66. Mi S, Lee X, Shao Z, et al. LINGO-1 is a component of the Nogo-66 receptor/p75 signaling complex. Nat Neurosci. 2004;7(3): 221-228.

67. Chao MV, Rajagopal R, Lee FS. Neurotrophin signalling in health and disease. Clin Sci. 2006;110(2):167-173.

68. Zotti T, Vito P, Stilo R. The seventh ring: exploring TRAF7 functions. J Cell Physiol. 2012;227(3):1280-1284.

69. Kanamoto T, Mota M, Takeda K, et al. Role of apoptosis signalregulating kinase in regulation of the c-Jun $\mathrm{N}$-terminal kinase pathway and apoptosis in sympathetic neurons. Mol Cell Biol. 2000;20(1): 196-204.

70. Dhanasekaran DN, Reddy EP. JNK signaling in apoptosis. Oncogene. 2008;27(48):6245-6251.

71. MacLachlan TK, El-Deiry WS. Apoptotic threshold is lowered by p53 transactivation of caspase-6. Proc Natl Acad Sci U S A. 2002;99(14): 9492-9497.

72. Miyashita T, Reed JC. Tumor suppressor p53 is a direct transcriptional activator of the human bax gene. Cell. 1995;80(2):293-299.

73. Bogoyevitch MA, Kobe B. Uses for JNK: the many and varied substrates of the c-Jun N-terminal kinases. Microbiol Mol Biol Rev. 2006;70(4): 1061-1095.

74. Karin M, Lin A. NF- $\kappa$ B at the crossroads of life and death. Nat Immunol. 2002;3(3):221-227.

75. Gentry JJ, Barker PA, Carter BD. The p75 neurotrophin receptor: multiple interactors and numerous functions. Prog Brain Res. 2004;146: $25-39$.

76. Dobrowsky RT, Werner MH, Castellino AM, Chao MV, Hannun YA. Activation of the sphingomyelin cycle through the low-affinity neurotrophin receptor. Science. 1994;265(5178):1596-1599.

77. Lewin GR, Carter BD. Neurotrophic Factors - Handbook of Experimental Pharmacology, vol. 220. Berlin, Heidelberg: Springer-Verlag; 2014:129.

78. Jonas JB, Bourne RR, White RA, et al. Visual impairment and blindness due to macular diseases globally: a systematic review and meta-analysis. Am J Ophthalmol. 2014;158(4):808-815.

79. Bourne RR, Jonas JB, Flaxman SR, et al. Prevalence and causes of vision loss in high-income countries and in Eastern and Central Europe: 1990-2010. Br J Ophthalmol. 2014;98(5):629-638.

80. Nickells RW, Zack DJ. Apoptosis in ocular disease: a molecular overview. Ophthalmic Genet. 1996;17(4):145-165.

81. Quigley HA. Neuronal death in glaucoma. Prog Retin Eye Res. 1999; 18(1):39-57.

82. Bernstein SL, Guo Y, Kelman SE, Flower RW, Johnson MA. Functional and cellular responses in a novel rodent model of anterior ischemic optic neuropathy. Invest Ophthalmol Vis Sci. 2003;44(10): 4153-4162.

83. Medeiros NE, Curcio CA. Preservation of ganglion cell layer neurons in age-related macular degeneration. Invest Ophthalmol Vis Sci. 2001;42(3):795-803.

84. Kern TS, Barber AJ. Retinal ganglion cells in diabetes. $J$ Physiol. 2008;586(Pt 18):4401-4408.

85. Shindler KS, Guan Y, Ventura E, Bennett J, Rostami A. Retinal ganglion cell loss induced by acute optic neuritis in a relapsing model of multiple sclerosis. Mult Scler. 2006;12(5):526-532.

86. Johnson JE, Barde YA, Schwab M, Thoenen H. Brain-derived neurotrophic factor supports the survival of cultured rat retinal ganglion cells. J Neurosci. 1986;6(10):3031-3038.

87. Di Polo A, Cheng L, Bray GM, Aguayo AJ. Colocalization of TrkB and brain-derived neurotrophic factor proteins in green-red-sensitive cone outer segments. Invest Ophthalmol Vis Sci. 2000;41(12): 4014-4021.

88. Cellerino A, Kohler K. Brain-derived neurotrophic factor/neurotrophin-4 receptor TrkB is localized on ganglion cells and dopaminergic amacrine cells in the vertebrate retina. J Comp Neurol. 1997;386(1): 149-160.
89. Rohrer B, Korenbrot JI, LaVail MM, Reichardt LF, Xu B. Role of neurotrophin receptor TrkB in the maturation of rod photoreceptors and establishment of synaptic transmission to the inner retina. J Neurosci. 1999;19(20):8919-8930.

90. Jelsma TN, Friedman HH, Berkelaar M, Bray GM, Aguayo AJ. Different forms of the neurotrophin receptor trkB mRNA predominate in rat retina and optic nerve. J Neurobiol. 1993;24(9):1207-1214.

91. Steuer H, Jaworski A, Elger B, et al. Functional characterization and comparison of the outer blood-retina barrier and the blood-brain barrier. Invest Ophthalmol Vis Sci. 2005;46(3):1047-1053.

92. Mansour-Robaey S, Clarke DB, Wang YC, Bray GM, Aguayo J. Effects of ocular injury and administration of brain-derived neurotrophic factor on survival and regrowth of axotomized retinal ganglion cells. Proc Natl Acad Sci U S A. 1994;91(5): $1632-1636$.

93. Klocker N, Kermer P, Weishaupt JH, Labes M, Ankerhold R, Bahr M. Brain-derived neurotrophic factor-mediated neuroprotection of adult rat retinal ganglion cells in vivo does not exclusively depend on phosphatidyl-inositol-3'-kinase/protein kinase B signaling. J Neurosci. 2000;20(18):6962-6967.

94. Nakazawa T, Tamai M, Mori N. Brain-derived neurotrophic factor prevents axotomized retinal ganglion cell death through MAPK and PI3K signaling pathways. Invest Ophthalmol Vis Sci. 2002;43(10):3319-3326.

95. Weibel D, Cadelli D, Schwab ME. Regeneration of lesioned rat optic nerve fibers is improved after neutralization of myelin-associated neurite growth inhibitors. Brain Res. 1994;642(1-2):259-266.

96. Weibel D, Kreutzberg GW, Schwab ME. Brain-derived neurotrophic factor (BDNF) prevents lesion-induced axonal die-back in young rat optic nerve. Brain Res. 1995;679(2):249-254.

97. Chen $\mathrm{H}$, Weber AJ. BDNF enhances retinal ganglion cell survival in cats with optic nerve damage. Invest Ophthalmol Vis Sci. 2001;42(5): 966-974.

98. Galindo-Romero C, Valiente-Soriano FJ, Jimenez-Lopez M, et al. Effect of brain-derived neurotrophic factor on mouse axotomized retinal ganglion cells and phagocytic microglia. Invest Ophthalmol Vis Sci. 2013;54(2):974-985.

99. Zhang CW, Lu Q, You SW, et al. CNTF and BDNF have similar effects on retinal ganglion cell survival but differential effects on nitric oxide synthase expression soon after optic nerve injury. Invest Ophthalmol Vis Sci. 2005;46(4):1497-1503.

100. LaVail MM, Gorrin GM. Protection from light damage by ocular pigmentation: analysis using experimental chimeras and translocation mice. Exp Eye Res. 1987;44(6):877-889.

101. Ko ML, Hu DN, Ritch R, Sharma SC. The combined effect of brain-derived neurotrophic factor and a free radical scavenger in experimental glaucoma. Invest Ophthalmol Vis Sci. 2000;41(10): 2967-2971.

102. Ikeda K, Tanihara H, Honda Y, Tatsuno T, Noguchi H, Nakayama C. BDNF attenuates retinal cell death caused by chemically induced hypoxia in rats. Invest Ophthalmol Vis Sci. 1999;40(9):2130-2140.

103. Kido N, Tanihara H, Honjo M, et al. Neuroprotective effects of brainderived neurotrophic factor in eyes with NMDA-induced neuronal death. Brain Res. 2000;884(1-2):59-67.

104. Tomita M, Adachi Y, Yamada H, et al. Bone marrow-derived stem cells can differentiate into retinal cells in injured rat retina. Stem Cells. 2002;20(4):279-283.

105. Lawrence JM, Keegan DJ, Muir EM, et al. Transplantation of Schwann cell line clones secreting GDNF or BDNF into the retinas of dystrophic Royal College of Surgeons rats. Invest Ophthalmol Vis Sci. 2004;45(1): 267-274.

106. Cellerino A, Pinzon-Duarte G, Carroll P, Kohler K. Brain-derived neurotrophic factor modulates the development of the dopaminergic network in the rodent retina. $J$ Neurosci. 1998;18(9): 3351-3362.

107. Mey J, Thanos S. Intravitreal injections of neurotrophic factors support the survival of axotomized retinal ganglion cells in adult rats in vivo. Brain Res. 1993;602(2):304-317. 
108. LaVail MM, Yasumura D, Matthes MT, et al. Protection of mouse photoreceptors by survival factors in retinal degenerations. Invest Ophthalmol Vis Sci. 1998;39(3):592-602.

109. Chen H, Weber AJ. Brain-derived neurotrophic factor reduces TrkB protein and mRNA in the normal retina and following optic nerve crush in adult rats. Brain Res. 2004;1011(1):99-106.

110. Marticorena J, Romano V, Gomez-Ulla F. Sterile endophthalmitis after intravitreal injections. Mediators Inflamm. 2012;2012: 928123

111. Suzuki T, Ooto S, Akagi T, et al. Effects of prolonged delivery of brain-derived neurotrophic factor on the fate of neural stem cells transplanted into the developing rat retina. Biochem Biophys Res Commun. 2003;309(4):843-847.

112. Fu QL, Li X, Yip HK, et al. Combined effect of brain-derived neurotrophic factor and LINGO-1 fusion protein on long-term survival of retinal ganglion cells in chronic glaucoma. Neuroscience. 2009;162(2): 375-382.

113. Koeberle PD, Ball AK. Neurturin enhances the survival of axotomized retinal ganglion cells in vivo: combined effects with glial cell linederived neurotrophic factor and brain-derived neurotrophic factor. Neuroscience. 2002;110(3):555-567.

114. Watanabe M, Tokita Y, Kato M, Fukuda Y. Intravitreal injections of neurotrophic factors and forskolin enhance survival and axonal regeneration of axotomized beta ganglion cells in cat retina. Neuroscience. 2003;116(3):733-742.

115. Tropea D, Caleo M, Maffei L. Synergistic effects of brain-derived neurotrophic factor and chondroitinase $\mathrm{ABC}$ on retinal fiber sprouting after denervation of the superior colliculus in adult rats. $J$ Neurosci. 2003;23(18):7034-7044.

116. Klocker N, Cellerino A, Bahr M. Free radical scavenging and inhibition of nitric oxide synthase potentiates the neurotrophic effects of brain-derived neurotrophic factor on axotomized retinal ganglion cells in vivo. J Neurosci. 1998;18(3):1038-1046.

117. Weber AJ, Viswanathan S, Ramanathan C, Harman CD. Combined application of BDNF to the eye and brain enhances ganglion cell survival and function in the cat after optic nerve injury. Invest Ophthalmol Vis Sci. 2010;51(1):327-334.

118. Guy J, Qi X, Muzyczka N, Hauswirth WW. Reporter expression persists 1 year after adeno-associated virus-mediated gene transfer to the optic nerve. Arch Ophthalmol. 1999;117(7):929-937.

119. Xiao X, Li J, McCown TJ, Samulski RJ. Gene transfer by adenoassociated virus vectors into the central nervous system. Exp Neurol. 1997;144(1):113-124.

120. Bennett J, Wilson J, Sun D, Forbes B, Maguire A. Adenovirus vector-mediated in vivo gene transfer into adult murine retina. Invest Ophthalmol Vis Sci. 1994;35(5):2535-2542.

121. Di Polo A, Aigner LJ, Dunn RJ, Bray GM, Aguayo AJ. Prolonged delivery of brain-derived neurotrophic factor by adenovirus-infected Müller cells temporarily rescues injured retinal ganglion cells. Proc Natl Acad Sci U S A. 1998;95(7):3978-3983.

122. Gauthier R, Joly S, Pernet V, Lachapelle P, Di Polo A. Brain-derived neurotrophic factor gene delivery to muller glia preserves structure and function of light-damaged photoreceptors. Invest Ophthalmol Vis Sci. 2005;46(9):3383-3392.

123. Schuettauf F, Vorwerk C, Naskar R, et al. Adeno-associated viruses containing bFGF or BDNF are neuroprotective against excitotoxicity. Curr Eye Res. 2004;29(6):379-386.

124. Martin KR, Quigley HA, Zack DJ, et al. Gene therapy with brainderived neurotrophic factor as a protection: retinal ganglion cells in a rat glaucoma model. Invest Ophthalmol Vis Sci. 2003;44(10): 4357-4365.

125. Mo X, Yokoyama A, Oshitari T, et al. Rescue of axotomized retinal ganglion cells by BDNF gene electroporation in adult rats. Invest Ophthalmol Vis Sci. 2002;43(7):2401-2405.

126. Ferrari FK, Samulski T, Shenk T, Samulski RJ. Second-strand synthesis is a rate-limiting step for efficient transduction by recombinant adeno-associated virus vectors. J Virol. 1996;70(5): $3227-3234$
127. Ren R, Li Y, Liu Z, Liu K, He S. Long-term rescue of rat retinal ganglion cells and visual function by AAV-mediated BDNF expression after acute elevation of intraocular pressure. Invest Ophthalmol Vis Sci. 2012;53(2):1003-1011.

128. Zhang Y, Wang W. Effects of bone marrow mesenchymal stem cell transplantation on light-damaged retina. Invest Ophthalmol Vis Sci. 2010;51(7):3742-3748.

129. Park HY, Kim JH, Sun Kim H, Park CK. Stem cell-based delivery of brain-derived neurotrophic factor gene in the rat retina. Brain Res. 2012;1469:10-23.

130. Zhou X-M, Yuan H-P, Wu D-L, et al. Study of brain-derived neurotrophic factor gene transgenic neural stem cells in the rat retina. Chin Med J (Engl). 2009;122(14):1642.

131. Roth JC, Curiel DT, Pereboeva L. Cell vehicle targeting strategies. Gene Ther. 2008;15(10):716-729.

132. Abe T, Wakusawa R, Seto H, Asai N, Saito T, Nishida K. Topical doxycycline can induce expression of BDNF in transduced retinal pigment epithelial cells transplanted into the subretinal space. Invest Ophthalmol Vis Sci. 2008;49(8):3631-3639.

133. Goldenberg-Cohen N, Avraham-Lubin BC, Sadikov T, Askenasy N. Effect of coadministration of neuronal growth factors on neuroglial differentiation of bone marrow-derived stem cells in the ischemic retina. Invest Ophthalmol Vis Sci. 2014;55(1):502-512.

134. Johnson TV, Bull ND, Martin KR. Neurotrophic factor delivery as a protective treatment for glaucoma. Exp Eye Res. 2011;93(2):196-203.

135. Edelhauser HF, Rowe-Rendleman CL, Robinson MR, et al. Ophthalmic drug delivery systems for the treatment of retinal diseases: basic research to clinical applications. Invest Ophthalmol Vis Sci. 2010; 51(11):5403-5420.

136. Kaur IP, Kakkar S. Nanotherapy for posterior eye diseases. J Control Release. 2014;193:100-112.

137. Sakai T, Kuno N, Takamatsu F, et al. Prolonged protective effect of basic fibroblast growth factor-impregnated nanoparticles in royal college of surgeons rats. Invest Ophthalmol Vis Sci. 2007;48(7):3381-3387.

138. WHO. Deafness and Hearing Loss. Switzerland, Geneva: WHO; 2014. Available from: http://www.who.int/mediacentre/factsheets/fs300/en/. Accessed October 2, 2014.

139. Fellinger J, Holzinger D, Gerich J, Goldberg D. Mental distress and quality of life in the hard of hearing. Acta Psychiatr Scand. 2007; 115(3):243-245.

140. Wilson BS, Dorman MF. Cochlear implants: a remarkable past and a brilliant future. Hear Res. 2008;242(1-2):3-21.

141. Fritzsch B, Pirvola U, Ylikoski J. Making and breaking the innervation of the ear: neurotrophic support during ear development and its clinical implications. Cell Tissue Res. 1999;295(3):369-382.

142. Ernfors P, Lee KF, Jaenisch R. Mice lacking brain-derived neurotrophic factor develop with sensory deficits. Nature. 1994; 368(6467):147-150.

143. Fukui H, Wong HT, Beyer LA, et al. BDNF gene therapy induces auditory nerve survival and fiber sprouting in deaf Pou4f3 mutant mice. Sci Rep. 2012;2:838.

144. Juhn SK, Haugen J, Steven L. Some chemical parameters of serum, cerebrospinal fluid, perilymph, and aqueous humor of the chinchilla. Lab Anim Sci. 1974;24(4):691-695.

145. Staecker H, Brough DE, Praetorius M, Baker K. Drug delivery to the inner ear using gene therapy. Otolaryngol Clin North Am. 2004;37(5): 1091-1108.

146. Budenz CL, Pfingst BE, Raphael Y. The use of neurotrophin therapy in the inner ear to augment cochlear implantation outcomes. Anat Rec (Hoboken). 2012;295(11):1896-1908.

147. Johnsson LG, Hawkins JE Jr. Strial atrophy in clinical and experimental deafness. Laryngoscope. 1972;82(7):1105-1125.

148. Meen E, Blakley B, Quddusi T. Brain-derived nerve growth factor in the treatment of sensorineural hearing loss. Laryngoscope. 2009;119(8) $1590-1593$

149. Shoji F, Miller AL, Mitchell A, Yamasoba T, Altschuler RA, Miller JM. Differential protective effects of neurotrophins in the attenuation of noise-induced hair cell loss. Hear Res. 2000;146(1-2):134-142. 
150. Hendricks JL, Chikar JA, Crumling MA, Raphael Y, Martin DC. Localized cell and drug delivery for auditory prostheses. Hear Res. 2008;242(1-2):117-131.

151. Radeloff A, Smolders JW. Brain-derived neurotrophic factor treatment does not improve functional recovery after hair cell regeneration in the pigeon. Acta Otolaryngol. 2006;126(5):452-459.

152. Ruan RS, Leong SK, Mark I, Yeoh KH. Effects of BDNF and NT-3 on hair cell survival in guinea pig cochlea damaged by kanamycin treatment. Neuroreport. 1999;10(10):2067-2071.

153. Miller JM, Chi DH, O'Keeffe LJ, Kruszka P, Raphael Y, Altschuler RA. Neurotrophins can enhance spiral ganglion cell survival after inner hair cell loss. Int J Dev Neurosci. 1997;15(4-5):631-643.

154. Meen E, Blakley B, Quddusi T. Does intracochlear brain-derived nerve growth factor improve auditory brainstem click thresholds in sensorineural hearing loss? J Otolaryngol Head Neck Surg. 2010;39(3):232-235

155. Gillespie LN, Clark GM, Bartlett PF, Marzella PL. BDNF-induced survival of auditory neurons in vivo: cessation of treatment leads to accelerated loss of survival effects. J Neurosci Res. 2003;71(6):785-790.

156. Montero CN, Hefti F. Rescue of lesioned septal cholinergic neurons by nerve growth factor: specificity and requirement for chronic treatment. J Neurosci. 1988;8(8):2986-2999.

157. Leake PA, Hradek GT, Rebscher SJ, Snyder RL. Chronic intracochlear electrical stimulation induces selective survival of spiral ganglion neurons in neonatally deafened cats. Hear Res. 1991;54(2):251-271.

158. Mitchell A, Miller JM, Finger PA, Heller JW, Raphael Y, Altschuler RA. Effects of chronic high-rate electrical stimulation on the cochlea and eighth nerve in the deafened guinea pig. Hear Res. 1997;105(1-2): $30-43$.

159. Shepherd RK, Matsushima J, Martin RL, Clark GM. Cochlear pathology following chronic electrical stimulation of the auditory nerve: II. Deafened kittens. Hear Res. 1994;81(1-2):150-166.

160. Leake PA, Stakhovskaya O, Hetherington A, Rebscher SJ, Bonham B. Effects of brain-derived neurotrophic factor (BDNF) and electrical stimulation on survival and function of cochlear spiral ganglion neurons in deafened, developing cats. J Assoc Res Otolaryngol. 2013;14(2): 187-211.

161. Song BN, Li YX, Han DM. Delayed electrical stimulation and BDNF application following induced deafness in rats. Acta Otolaryngol. 2009;129(2):142-154

162. Landry TG, Wise AK, Fallon JB, Shepherd RK. Spiral ganglion neuron survival and function in the deafened cochlea following chronic neurotrophic treatment. Hear Res. 2011;282(1-2):303-313.

163. Shepherd RK, Coco A, Epp SB. Neurotrophins and electrical stimulation for protection and repair of spiral ganglion neurons following sensorineural hearing loss. Hear Res. 2008;242(1-2):100-109.

164. Maruyama J, Miller JM, Ulfendahl M. Glial cell line-derived neurotrophic factor and antioxidants preserve the electrical responsiveness of the spiral ganglion neurons after experimentally induced deafness. Neurobiol Dis. 2008;29(1):14-21.

165. Glueckert R, Bitsche M, Miller JM, et al. Deafferentation-associated changes in afferent and efferent processes in the guinea pig cochlea and afferent regeneration with chronic intrascalar brain-derived neurotrophic factor and acidic fibroblast growth factor. J Comp Neurol. 2008;507(4):1602-1621.

166. Hartnick CJ, Staecker H, Malgrange B, et al. Neurotrophic effects of BDNF and CNTF, alone and in combination, on postnatal day 5 rat acoustic ganglion neurons. J Neurobiol. 1996;30(2):246-254.

167. Pettingill LN, Richardson RT, Wise AK, O’Leary SJ, Shepherd RK. Neurotrophic factors and neural prostheses: potential clinical applications based upon findings in the auditory system. IEEE Trans Biomed Eng. 2007;54(6 Pt 1):1138-1148.

168. Sacheli R, Delacroix L, Vandenackerveken P, Nguyen L, Malgrange B. Gene transfer in inner ear cells: a challenging race. Gene Ther. 2013; 20(3):237-247.

169. Wise AK, Hume CR, Flynn BO, et al. Effects of localized neurotrophin gene expression on spiral ganglion neuron resprouting in the deafened cochlea. Mol Ther. 2010;18(6):1111-1122.
170. Staecker H, Gabaizadeh R, Federoff H, Van De Water TR. Brainderived neurotrophic factor gene therapy prevents spiral ganglion degeneration after hair cell loss. Otolaryngol Head Neck Surg. 1998;119(1):7-13.

171. Rejali D, Lee VA, Abrashkin KA, Humayun N, Swiderski DL, Raphael Y. Cochlear implants and ex vivo BDNF gene therapy protect spiral ganglion neurons. Hear Res. 2007;228(1-2):180-187.

172. Nakaizumi T, Kawamoto K, Minoda R, Raphael Y. Adenovirus-mediated expression of brain-derived neurotrophic factor protects spiral ganglion neurons from ototoxic damage. Audiol Neurootol. 2004;9(3): 135-143.

173. Chikar JA, Colesa DJ, Swiderski DL, Di Polo A, Raphael Y, Pfingst BE. Over-expression of BDNF by adenovirus with concurrent electrical stimulation improves cochlear implant thresholds and survival of auditory neurons. Hear Res. 2008;245(1-2):24-34.

174. Holt JR, Johns DC, Wang S, et al. Functional expression of exogenous proteins in mammalian sensory hair cells infected with adenoviral vectors. J Neurophysiol. 1999;81(4):1881-1888.

175. Stone IM, Lurie DI, Kelley MW, Poulsen DJ. Adeno-associated virusmediated gene transfer to hair cells and support cells of the murine cochlea. Mol Ther. 2005;11(6):843-848.

176. Duan ML, Bordet T, Mezzina M, Kahn A, Ulfendahl M. Adenoviral and adeno-associated viral vector mediated gene transfer in the guinea pig cochlea. Neuroreport. 2002;13(10):1295-1299.

177. Shibata SB, Cortez SR, Beyer LA, et al. Transgenic BDNF induces nerve fiber regrowth into the auditory epithelium in deaf cochleae. Exp Neurol. 2010;223(2):464-472.

178. Ito J, Endo T, Nakagawa T, Kita T, Kim TS, Iguchi F. A new method for drug application to the inner ear. ORL J Otorhinolaryngol Relat Spec. 2005;67(5):272-275.

179. Havenith S, Versnel H, Agterberg MJ, et al. Spiral ganglion cell survival after round window membrane application of brain-derived neurotrophic factor using gelfoam as carrier. Hear Res. 2011; 272(1-2):168-177.

180. Sakamoto T, Nakagawa T, Horie RT, et al. Inner ear drug delivery system from the clinical point of view. Acta Otolaryngol Suppl. 2010; (563):101-104.

181. Gillespie LN, Shepherd RK. Clinical application of neurotrophic factors: the potential for primary auditory neuron protection. Eur $J$ Neurosci. 2005;22(9):2123-2133.

182. Pettingill LN, Wise AK, Geaney MS, Shepherd RK. Enhanced auditory neuron survival following cell-based BDNF treatment in the deaf guinea pig. PloS One. 2011;6(4):e18733.

183. Di Toro R, Betti V, Spampinato S. Biocompatibility and integrinmediated adhesion of human osteoblasts to poly (DL-lactide-coglycolide) copolymers. Eur J Pharm Sci. 2004;21(2):161-169.

184. Tamura T, Kita T, Nakagawa T, et al. Drug delivery to the cochlea using PLGA nanoparticles. Laryngoscope. 2005;115(11):2000-2005.

185. Ge X, Jackson RL, Liu J, et al. Distribution of PLGA nanoparticles in chinchilla cochleae. Otolaryngol Head Neck Surg. 2007;137(4): 619-623.

186. Arlinger S. Negative consequences of uncorrected hearing loss $-\mathrm{a}$ review. Int J Audiol. 2003;42(Suppl 2):2S17-2S20.

187. Horowitz A. The prevalence and consequences of vision impairment in later life. Top Geriatr Rehabil. 2004;20(3):185-195.

188. Kirk EC, Gosselin-Ildari AD. Cochlear labyrinth volume and hearing abilities in primates. Anat Rec (Hoboken). 2009;292(6):765-776.

189. Frank L, Wiegand SJ, Siuciak JA, Lindsay RM, Rudge JS. Effects of BDNF infusion on the regulation of TrkB protein and message in adult rat brain. Exp Neurol. 1997;145(1):62-70.

190. Scharfman HE, Goodman JH, Sollas AL, Croll SD. Spontaneous limbic seizures after intrahippocampal infusion of brain-derived neurotrophic factor. Exp Neurol. 2002;174(2):201-214.

191. Binder DK, Croll SD, Gall CM, Scharfman HE. BDNF and epilepsy: too much of a good thing? Trends Neurosci. 2001;24(1):47-53.

192. Shinohara T, Bredberg G, Ulfendahl M, et al. Neurotrophic factor intervention restores auditory function in deafened animals. Proc Natl Acad Sci U S A. 2002;99(3):1657-1660. 
193. Shepherd RK, Coco A, Epp SB, Crook JM. Chronic depolarization enhances the trophic effects of brain-derived neurotrophic factor in rescuing auditory neurons following a sensorineural hearing loss. J Comp Neurol. 2005;486(2):145-158.

194. Xiao X, Li J, Samulski RJ. Efficient long-term gene transfer into muscle tissue of immunocompetent mice by adeno-associated virus vector. J Virol. 1996;70(11):8098-8108.

195. Sieving PA, Caruso RC, Tao W, et al. Ciliary neurotrophic factor (CNTF) for human retinal degeneration: phase I trial of CNTF delivered by encapsulated cell intraocular implants. Proc Natl Acad Sci U S A. 2006;103(10):3896-3901.

196. Adunka O, Unkelbach MH, Mack M, Hambek M, Gstoettner W, Kiefer J. Cochlear implantation via the round window membrane minimizes trauma to cochlear structures: a histologically controlled insertion study. Acta Otolaryngol. 2004;124(7):807-812.

197. Unoki K, LaVail MM. Protection of the rat retina from ischemic injury by brain-derived neurotrophic factor, ciliary neurotrophic factor, and basic fibroblast growth factor. Invest Ophthalmol Vis Sci. 1994;35(3):907-915.

198. Sawai H, Clarke DB, Kittlerova P, Bray GM, Aguayo AJ. Brainderived neurotrophic factor and neurotrophin- $4 / 5$ stimulate growth of axonal branches from regenerating retinal ganglion cells. J Neurosci. 1996;16(12):3887-3894.

199. Peinado-Ramon P, Salvador M, Villegas-Perez MP, Vidal-Sanz M. Effects of axotomy and intraocular administration of NT-4, NT-3, and brain-derived neurotrophic factor on the survival of adult rat retinal ganglion cells. A quantitative in vivo study. Invest Ophthalmol Vis Sci. 1996;37(4):489-500.

200. Cellerino A, Arango-Gonzalez BA, Kohler K. Effects of brain-derived neurotrophic factor on the development of NADPH-diaphorase/nitric oxide synthase-positive amacrine cells in the rodent retina. Eur $J$ Neurosci. 1999;11(8):2824-2834.

201. Kurokawa T, Katai N, Shibuki H, et al. BDNF diminishes caspase-2 but not c-Jun immunoreactivity of neurons in retinal ganglion cell layer after transient ischemia. Invest Ophthalmol Vis Sci. 1999;40(12):3006-3011.

202. Chen H, Weber AJ. Expression of glial fibrillary acidic protein and glutamine synthetase by Müller cells after optic nerve damage and intravitreal application of brain-derived neurotrophic factor. Glia. 2002;38(2):115-125.

203. Ota T, Hara H, Miyawaki N. Brain-derived neurotrophic factor inhibits changes in soma-size of retinal ganglion cells following optic nerve axotomy in rats. J Ocul Pharmacol Ther. 2002;18(3):241-249.

204. Krueger-Naug A, Emsley J, Myers T, Currie R, Clarke D. Administration of brain-derived neurotrophic factor suppresses the expression of heat shock protein 27 in rat retinal ganglion cells following axotomy. Neuroscience. 2003;116(1):49-58.

205. Lee EJ, Song MC, Kim HJ, et al. Brain-derived neurotrophic factor modulates the dopaminergic network in the rat retina after axotomy. Cell Tissue Res. 2005;322(2):191-199.

206. Chen R, Yin XB, Peng CX, Li GL. Effect of brain-derived neurotrophic factor on c-jun expression in the rd mouse retina. Int $J$ Ophthalmol. 2012;5(3):266-271

207. Yan Q, Wang J, Matheson CR, Urich JL. Glial cell line-derived neurotrophic factor (GDNF) promotes the survival of axotomized retinal ganglion cells in adult rats: comparison to and combination with brain-derived neurotrophic factor (BDNF). J Neurobiol. 1999;38(3): 382-390.

International Journal of Nanomedicine

\section{Publish your work in this journal}

The International Journal of Nanomedicine is an international, peerreviewed journal focusing on the application of nanotechnology in diagnostics, therapeutics, and drug delivery systems throughout the biomedical field. This journal is indexed on PubMed Central, MedLine, CAS, SciSearch $\AA$, Current Contents ${ }^{\circledR} /$ Clinical Medicine,
208. Weber AJ, Harman CD. BDNF treatment and extended recovery from optic nerve trauma in the cat. Invest Ophthalmol Vis Sci. 2013;54(10): 6594-6604.

209. Wang JM, Sun NX, Hui N, Fan YZ, Feng HX, Zhao SP. [Effects of rAAV-mediated rhBDNF gene transfection on BDNF gene expression in the retina of a rabbit model of acute high intraocular pressure]. Nan Fang Yi Ke Da Xue Xue Bao. 2009;29(11):2201-2204. Chinese.

210. Wan C, Liu NN, Liu LM, Cai N, Chen L. Effect of adenovirusmediated brain derived neurotrophic factor in early retinal neuropathy of diabetes in rats. Int J Ophthalmol. 2010;3(2):145-148.

211. McGuinness SL, Shepherd RK. Exogenous BDNF rescues rat spiral ganglion neurons in vivo. Otol Neurotol. 2005;26(5):1064-1072.

212. Agterberg MJ, Versnel H, de Groot JC, Smoorenburg GF, Albers FW, Klis SF. Morphological changes in spiral ganglion cells after intracochlear application of brain-derived neurotrophic factor in deafened guinea pigs. Hear Res. 2008;244(1-2):25-34.

213. Song BN, Li YX, Han DM. Effects of delayed brain-derived neurotrophic factor application on cochlear pathology and auditory physiology in rats. Chin Med J. 2008;121(13):1189-1196.

214. Agterberg MJ, Versnel H, van Dijk LM, de Groot JC, Klis SF. Enhanced survival of spiral ganglion cells after cessation of treatment with brain-derived neurotrophic factor in deafened guinea pigs. $J$ Assoc Res Otolaryngol. 2009;10(3):355-367.

215. Sly DJ, Hampson AJ, Minter RL, et al. Brain-derived neurotrophic factor modulates auditory function in the hearing cochlea. $J$ Assoc Res Otolaryngol. 2012;13(1):1-16.

216. Leake PA, Hradek GT, Hetherington AM, Stakhovskaya O. Brainderived neurotrophic factor promotes cochlear spiral ganglion cell survival and function in deafened, developing cats. J Comp Neurol. 2011;519(8):1526-1545.

217. Waaijer L, Klis SF, Ramekers D, Van Deurzen MH, Hendriksen FG, Grolman W. The peripheral processes of spiral ganglion cells after intracochlear application of brain-derived neurotrophic factor in deafened guinea pigs. Otol Neurotol. 2013;34(3):570-578.

218. van Loon MC, Ramekers D, Agterberg MJ, et al. Spiral ganglion cell morphology in guinea pigs after deafening and neurotrophic treatment. Hear Res. 2013;298:17-26.

219. Yamagata T, Miller JM, Ulfendahl M, et al. Delayed neurotrophic treatment preserves nerve survival and electrophysiological responsiveness in neomycin-deafened guinea pigs. J Neurosci Res. 2004;78(1):75-86.

220. Wise AK, Richardson R, Hardman J, Clark G, O'Leary S. Resprouting and survival of guinea pig cochlear neurons in response to the administration of the neurotrophins brain-derived neurotrophic factor and neurotrophin-3. J Comp Neurol. 2005;487(2):147-165.

221. Miller JM, Le Prell CG, Prieskorn DM, Wys NL, Altschuler RA. Delayed neurotrophin treatment following deafness rescues spiral ganglion cells from death and promotes regrowth of auditory nerve peripheral processes: effects of brain-derived neurotrophic factor and fibroblast growth factor. J Neurosci Res. 2007;85(9):1959-1969.

222. Lalwani AK, Han JJ, Castelein CM, Carvalho GJ, Mhatre AN. In vitro and in vivo assessment of the ability of adeno-associated virus-brain-derived neurotrophic factor to enhance spiral ganglion cell survival following ototoxic insult. Laryngoscope. 2002;112(8): $1325-1334$.

223. Li L, Shui QX, Li X. Neuroprotective effects of brain-derived neurotrophic factor (BDNF) on hearing in experimental pneumococcal meningitis. J Child Neurol. 2005;20(1):51-56.

\section{Dovepress}

Journal Citation Reports/Science Edition, EMBase, Scopus and the Elsevier Bibliographic databases. The manuscript management system is completely online and includes a very quick and fair peer-review system, which is all easy to use. Visit http://www.dovepress.com/ testimonials.php to read real quotes from published authors. 